I19.3:1724-A

\title{
Mineral Resources of the Ruby Mountains Wilderness Study Area, Madison County, Montana
}

\section{U.S. GEOLOGICAL SURVEY BULLETIN 1724-A}

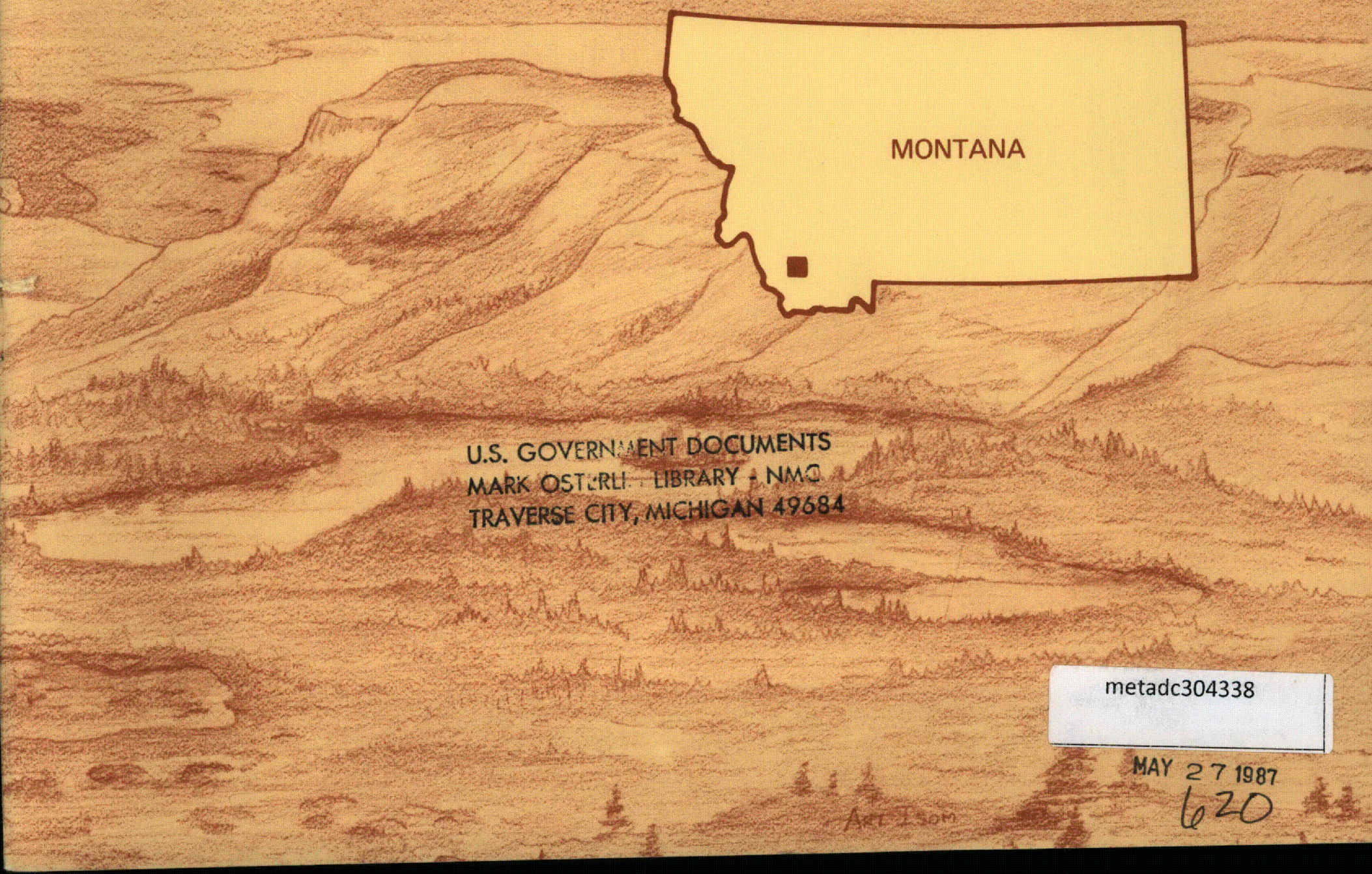


Chapter A

\section{Mineral Resources of the Ruby Mountains Wilderness Study Area, Madison County, Montana}

By R. G. TYSDAL, G. K. LEE,

J. H. HASSEMER, and W. F. HANNA

U.S. Geological Survey

S. W. SCHMAUCH

U.S. Bureau of Mines

With a section on Talc

By R. B. BERG

Montana Bureau of Mines and Geology

U.S. GEOLOGICAL SURVEY BULLETIN 1724

MINERAL RESOURCES OF WILDERNESS STUDY AREAS-

SOUTHWESTERN MONTANA 


\title{
DEPARTMENT OF THE INTERIOR DONALD PAUL HODEL, Secretary
}

\author{
U.S. GEOLOGICAL SURVEY \\ Dallas L. Peck, Director
}

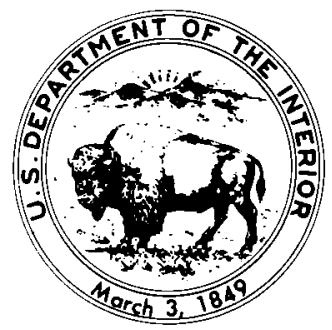

UNITED STATES GOVERNMENT PRINTING OFFICE, WASHINGTON: 1987

For sale by the

Books and Open-File Reports Section

U.S. Geological Survey

Federal Center

Box 25425

Denver, CO 80225

\section{Library of Congress Cataloging in Publication Data}

Mineral resources of the Ruby Mountains Wilderness Study Area, Madison County, Montana

(U.S. Geological Survey bulletin ; 1724-A)(Mineral resources of wilderness study areas-southwestern Montana; ch. A)

Bibliography: $p$.

Supt. of Docs. No.: | 19.3:1724

1. Mines and mineral resources-Montana-Ruby Mountains

Wilderness. 2. Ruby Mountains Wilderness (Mont.)

1. Tysdal, Russell G. II. Series: Ceological Survey bulletin ; 1724-A.
III. Series: Mineral resouces of wilderness study areas-southwestern Montana ; ch. A.

QE75.B9 no. 1724-A

[TN24.M9]

$557.3 \mathrm{~s}$

[553'.09786'663]

86-607948 


\section{STUDIES RELATED TO WILDERNESS}

\section{Bureau of Land Management Wilderness Study Areas}

The Federal Land Policy and Management Act (Public Law 94-979, October 21, 1976) requires the U.S. Geological Survey and the U.S. Bureau of Mines to conduct mineral surveys on certain areas to determine the mineral values, if any, that may be present. Results must be made available to the public and be submitted to the President and the Congress. This report presents the results of a mineral survey of part of the Ruby Mountains Wilderness Study Area (MT-076-001), Madison County, Montana. 



\section{CONTENTS}

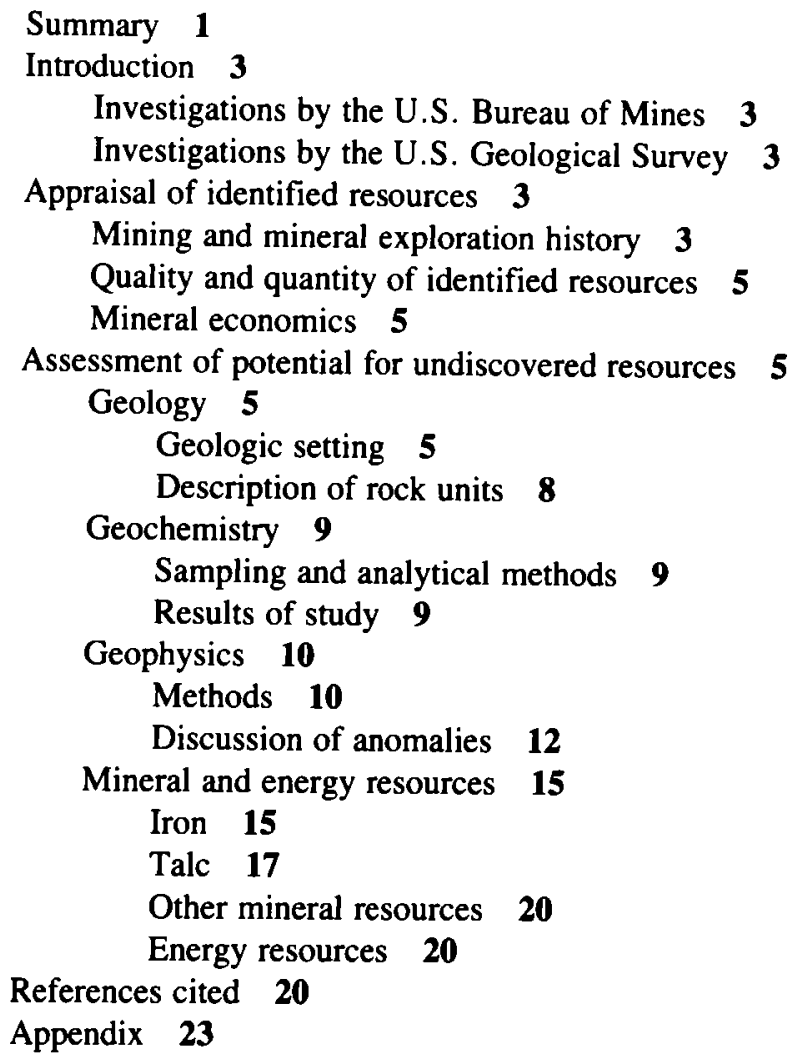

PLATE

1. Map showing mineral resource potential and geology of the Ruby Mountains study area In pocket

\section{FIGURES}

1. Map showing areas of mineral resource potential and prospects in the Ruby Mountains study area 2

2. Index map showing location of wilderness study area in the Ruby Mountains, southwestern Montana 4

3. Complete Bouguer gravity anomaly map and generalized geology in the vicinity of the Ruby Mountains study area $\mathbf{1 6}$

4. Aeromagnetic anomaly map and generalized geology in the vicinity of the Ruby Mountains study area 18

\section{TABLES}

1. Mines and prospects in and adjacent to the Ruby Mountains study area 6

2. Analyses of stream-sediment samples, Ruby Mountains study area $\mathbf{1 0}$

3. Analyses of heavy-mineral concentrate samples, Ruby Mountains study area 12

4. Analyses of rock samples, Ruby Mountains study area 14 



\title{
Mineral Resources of the Ruby Mountains Wilderness Study Area, Madison County, Montana
}

\author{
By R. G. Tysdal, G. K. Lee, J. H. Hassemer, and W. F. Hanna \\ U.S. Geological Survey
}

S. W. Schmauch

U.S. Bureau of Mines

With a section on Talc

By R. B. Berg

Montana Bureau of Mines and Geology

\section{Summary}

A mineral resource survey of the Ruby Mountains Wilderness Study Area (MT-076-001) was made in 1984 85. Thirty-two million tons of subeconomic mineral resources that average 21 percent iron occur in the Kelly iron deposit and constitute an identified resource adjacent to the southeasternmost edge of the study area. Moderate and high mineral resource potential for talc deposits occur within a large body of Archean (see geologic time chart in appendix) marble in the central part of the study area (fig. 1). The study area has a low mineral resource potential for uranium and for oil and gas sources. No phosphate deposits exist in the study area.

The Ruby Mountains Wilderness Study Area contains 15,615 acres in the northern part of the Ruby Range, Madison County, Montana (figs. 1, 2). Elevation of the study area ranges from about 5,000 to 9,400 feet ( $\mathrm{ft}$ ). The mountains at the east and north margins of the study area rise abruptly from the alluvial fans that flank the mountain range, but on the west the topographic contrast is less abrupt. The area is accessible by roads extending south and southwest from Montana State Highway 287, east from Montana State Highway 41, and west from the Upper Ruby River road.

The Ruby Range lies in the foreland of the Rocky Mountains and is composed of a basement of Archean metamorphic rocks. Sedimentary rocks of limestone, dolomite, and minor sandstone and shale overlie the base- ment in much of the study area and have an aggregate thickness of about 5,000 ft. Younger formations of consolidated sedimentary rocks, although at one time present in the area, have largely been eroded.

Rocks of the Ruby Range were deformed during the Laramide orogeny. Folds, and associated faults with vertical displacements of as much as a mile, formed during the course of the deformation and control erosion, giving rise to some of the present-day topographic contrasts within the range. The later development of distinct basins and ranges in southwestern Montana coincided with vertical displacements along faults that delimit the present-day margins of the Ruby Range. These basinand-range faults separate the mountainous wilderness study area from downdropped basins of sedimentary rock that underlie the Beaverhead River Valley on the west and the Ruby River valley to the north and east.

Field and laboratory studies were conducted to assess the mineral resource potential of the Ruby Mountains Wilderness Study Area. Much of the area had been mapped previously, but reconnaissance traverses were made to examine the rocks for evidence of mineral deposits of various types, and detailed study of Archean márble units was undertaken because they may contain undiscovered talc deposits. A geochemical study included spectrographic and chemical analyses of stream sediments, heavy-mineral concentrates, and rock samples collected by the U.S. Geological Survey (USGS); and examination, sampling, and analysis of rocks from mining claims, prospects, and mineral occurrences by the U.S. Bureau of Mines (USBM). 


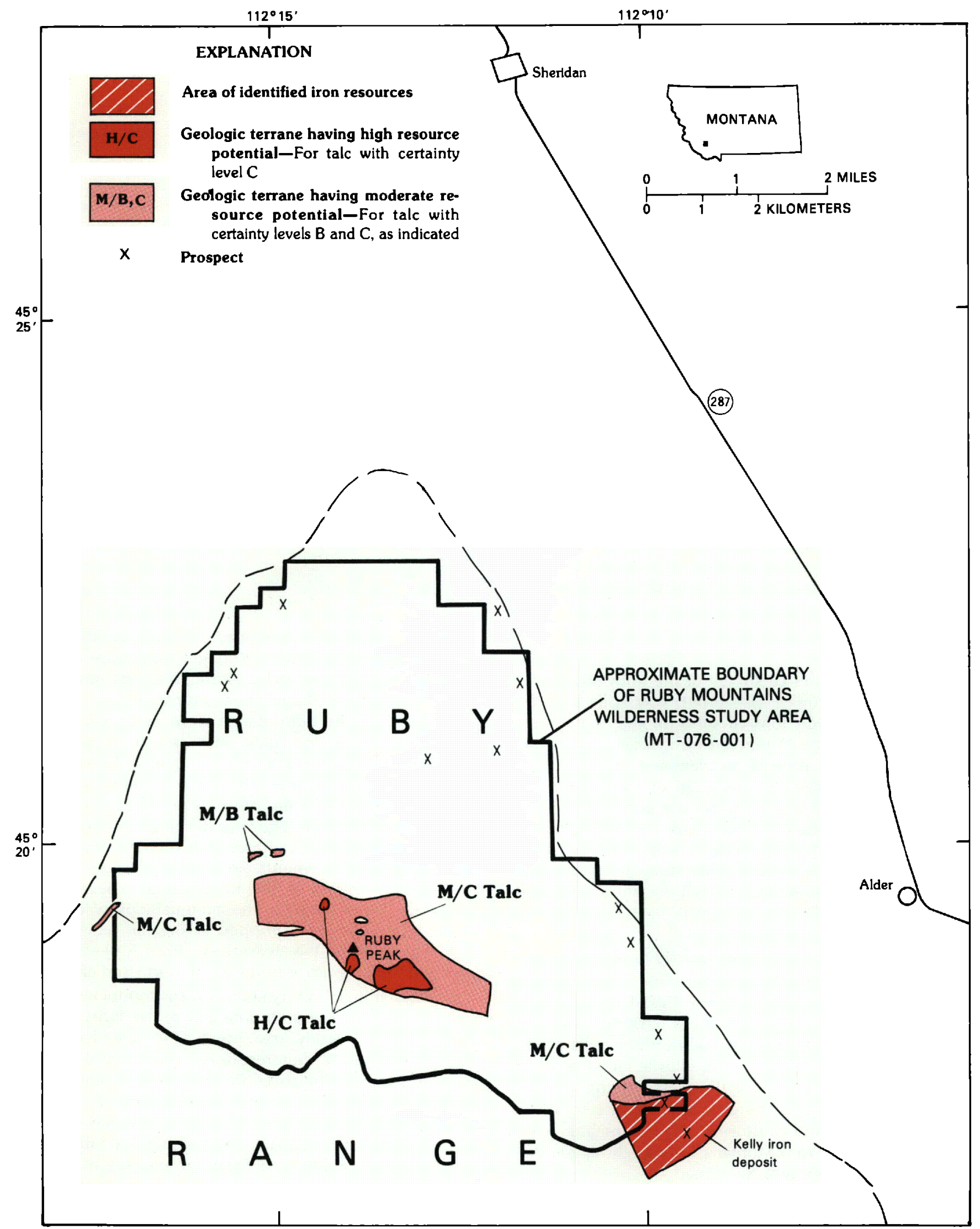

Figure 1. Map showing areas of mineral resource potential and prospects in the Ruby Mountains study area, Madison County, southwestern Montana. Extent of Ruby Range shown by dashed line. 
Prospecting for metals has taken place in and adjacent to the study area, as is made evident by numerous prospect pits along the east flank of the range. Most of the pits likely were excavated in a search for base (copper, lead, zinc) or precious (gold, silver) metals, but no deposits of this type were found. Identified resources of iron exist in the southeasternmost corner of the study area-part of the Kelly iron deposit that lies mainly on private land immediately outside the boundary of the area (fig. 1) in the Archean metamorphic rocks that form the basement of the region. Moderate and high potential for talc occur in Archean dolomitic marble in the central part of the study area. The talc formed from siliceous fluids that reacted with the dolomitic marble, an event that most likely occurred during Precambrian time but after the 2,750 m.y. metamorphic event.

A low potential exists for energy resources within the entire wilderness study area. Uranium occurrences were not found in the area, and the geologic setting of the immediate area is not considered favorable for oil and gas resources. Phosphate-bearing sedimentary strata have been eroded from the range.

\section{INTRODUCTION}

The USGS and the USBM studied 15,615 acres of the Ruby Mountains Wilderness Study Area (MT-076$001)$. The study of this acreage was requested by the U.S. Bureau of Land Management (BLM). In this report the area studied is called the "wilderness study area" or simply the "study area." The study area is located at the north end of the Ruby Range in Madison County, Montana (fig. 2, pl. 1). It is accessible by roads that extend south and southwest from Montana State Highway 287; east from Montana State Highway 41; and west from the Upper Ruby River road, which lies east of the wilderness study area. The elevation at the foot of the mountains is about $5,000 \mathrm{ft}$ and reaches a maximum of $9,391 \mathrm{ft}$ atop Ruby Peak, along the backbone of the range.

This report presents an evaluation of the mineral endowment (identified resources and mineral resource potential) of the study area and is the product of several separate studies by the U.S. Bureau of Mines (USBM) and the U.S. Geological Survey (USGS). Identified resources are classified according to the system of the USBM and the USGS (1980) which is shown in the appendix of this report. Mineral resource potential is the likelihood of occurrence of undiscovered concentrations of metals and nonmetals, of unappraised industrial rocks and minerals, and of undiscovered energy sources (coal, oil, gas, oil shale, and geothermal sources). It is classified according to the system of Goudarzi (1984) and is shown in the appendix of this report. The field work was carried out during the summers of 1984 and 1985.

\section{Investigations by the U.S. Bureau of Mines}

USBM personnel collected information about current and past mining activities from county mining records, pertinent literature, and from BLM mining records. A search was conducted in 1984 for all mines, prospects, mineralized zones, and claims. Properties were sampled and mapped where warranted. A total of 63 rock samples were collected, and all were analyzed for gold and silver; some also were analyzed for manganese, iron, copper, lead, zinc, or molybdenum; many were also analyzed by a semiquantitative spectrophotometric method for 43 elements. The complete results of the USBM work in this study area are included in Schmauch (1985).

\section{Investigations by the U.S. Geological Survey}

During the summers of 1984 and 1985, stream-sediment and heavy-mineral concentrate samples were collected from streams that drain the wilderness study area and were analyzed chemically and spectrographically. Selected rock samples were analyzed chemically to aid in the interpretation of the stream-sediment and concentrate data. New gravity measurements were made in and adjacent to the wilderness study area to more precisely define gravity anomaly features previously mapped by Petkewich (1972). Under a contract with the USGS, R. B. Berg, Montana Bureau of Mines and Geology (MBMG), carried out a detailed study of those Archean (older than 2,500 m.y.) rocks believed to be possible hosts for talc deposits. In this report, the term "deposit," unmodified, carries no connotation of economic value. The mineral resource potential was classified by type of deposit, level of potential, and level of certainty.

Acknowledgments.--The USGS and the USBM thank the many land owners in the area who granted us permission to cross their land to obtain data from the wilderness study area. The BLM staff at Dillon, Montana, provided data for the USBM investigations. John $R$. Benham, U.S. Bureau of Mines, participated in the USBM field studies. Professor R. M. Petkewich, Georgia State University, kindly provided the USGS with gravity data from his geologic work (Petkewich, 1972) in the basins marginal to the wilderness study area. That data aided in the geophysical interpretation.

\section{APPRAISAL OF IDENTIFIED RESOURCES}

\section{By S. W. Schmauch \\ U.S. Bureau of Mines}

\section{Mining and Mineral Exploration History}

Mining claims and prospects were examined by the USBM (pl. 1 and table 1). Eight mining claims were lo- 


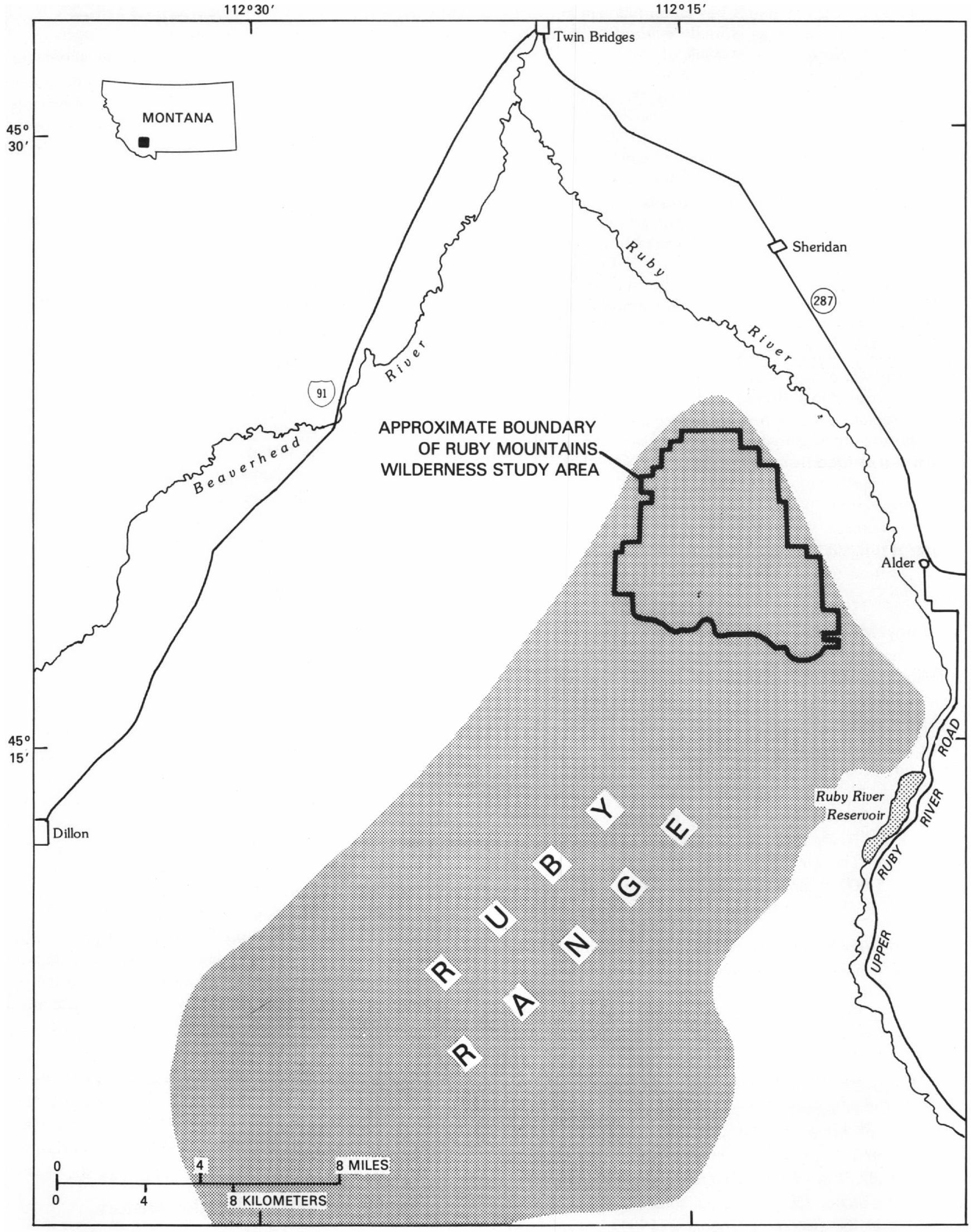

Figure 2. Index map showing location of Ruby Mountains study area in the Ruby Range, Madison County, southwestern Montana. 
cated along the eastern flank of the Ruby Range between 1886 and 1894 , mainly on iron or manganese stains. At Spring Canyon in the northwestern part of the study area, a claim (loc. 2P, pl. 1) was located for metals in 1923. A claim (loc. 3P, pl. 1) in the same Spring Canyon, and another near Ruby Peak (loc. 1P, pl. 1), were claimed for talc in 1953 and 1956, respectively; the latter claim was refiled in 1976.

Ten claims were located in Taylor Canyon in 1897; they are adjacent to the wildemess study area. Two of these, the Copper Queen and Rattlesnake (both at loc. 10P, pl. 1), were patented in 1901 but remain undeveloped. The Kelly iron deposit was discovered in 1932 and held by assessment work until 1963. During the late 1950's, several bulldozer trenches and at least two drill holes were used to explore the iron-formation. No current mining claims exist within the study area.

\section{Quality and Quantity of Identified Resources}

Only a small part of the Kelly iron deposit lies within the wilderness study area. The principal area of the deposit lies outside the study area and is estimated to contain 32 million tons that average 21 percent iron; the deposit is considered to be a subeconomic resource.

\section{Mineral Economics}

Identified resources at the Kelly iron deposit could be developed and mined concurrently with other similar iron deposits in the general region. A centralized or possibly portable processing facility could concentrate the iron ore prior to rail shipment; rail transportation and talc processing facilities are located on both sides of the Ruby Range. An increase in the value of iron ore and (or) the identification of a larger resource is needed for development. Open-pit mining at the Kelly mine would likely disturb an area of less than $1 \mathrm{sq} \mathrm{mi}$. The small portion of this deposit that lies inside the study area is too small and too remote to extract profitably at this time.

The term "marble" as used in this report, refers to limestone and (or) dolomite that has been recrystallized by metamorphism into medium- or coarse-grained metalimestone or metadolomite. It lacks most of the desirable physical characteristics associated with use as a building stone, and no resources were identified. Minor amounts of talc occur in the dolomitic horizons of the Archean marble in the study area. No identified resources of talc occur in the study area.

\section{ASSESSMENT OF POTENTIAL FOR} UNDISCOVERED RESOURCES

\author{
By R. G. Tysdal, G. K. Lee, J. H. Hassemer, and \\ W. F. Hanna \\ U.S. Geological Survey
}

\section{Geology}

\section{Geologic Setting}

The northern part of the Ruby Range, in which the wilderness study area lies, consists of a basement of Archean metamorphic rocks overlain by Paleozoic, Mesozoic, and Cenozoic sedimentary strata (see appendix for geologic time scale). The basement rocks were originally metamorphosed to a high metamorphic grade about 2,750 m.y. (James and Hedge, 1980) and underwent a second and milder thermal event about 1,600 m.y. (Giletti, 1966). The metamorphic rocks of the range have been referred to part of the Cherry Creek Group because of the abundance of rocks of probable sedimentary origin, including marble units (several hundred feet thick), quartzite, and iron-formation; however, correlation of these highly deformed and recrystallized rocks is difficult (James and Hedge, 1980), thus lithologic terms are used in this report.

The Paleozoic strata aggregate about $5,000 \mathrm{ft}$ thick and are composed largely of limestone and dolomite typical of the Rocky Mountain foreland in southwestern Montana. Mesozoic strata are represented only by rocks of the Late Cretaceous Beaverhead Group. Other Mesozoic strata of marine and nonmarine origin probably were deposited and subsequently eroded before deposition of the Beaverhead (Tysdal, 1976b).

Igneous rocks intruded the sedimentary strata after Late Cretaceous-Tertiary (Laramide) deformation. The intrusive rocks are chiefly sills and small-diameter (a few tens of feet across) pipelike bodies of basalt; andesitic and rhyolitic pipelike intrusions are present locally. A volcanic unit of andesitic tuff breccia and agglomerate is present in one place along the west side of the range (pl. 1).

During the Laramide orogeny, the mountain range was broken into blocks defined by steeply dipping faults that trend north and northwest. The faults record as much as $7,000 \mathrm{ft}$ of vertical displacement. Sedimentary strata on the uplifted sides of faults were deformed into anticlines, and strata on the downthrown sides were deformed into synclines. The folds plunge moderately to the northwest (Tysdal, 1976a; 1981). 
Table 1. Mines and prospects in and adjacent to the Ruby Mountains study area

[Properties within the study area are underscored]

\begin{tabular}{|c|c|c|c|c|}
\hline $\begin{array}{l}\text { No. } \\
\text { (plate 1) }\end{array}$ & $\begin{array}{l}\text { Property } \\
\text { Name }\end{array}$ & Summary & Workings & Sample data \\
\hline $1 \mathrm{P}$ & $\frac{\text { Unknown }}{(29,5,5)}$ & $\begin{array}{l}\text { Massive limestone strikes northwest and dips } \\
\text { northeast, and contains stromatolites and thin } \\
\text { lenses of calcareous siltstone. }\end{array}$ & One pit. & Une grab sample contained no significant values. \\
\hline $2 \mathrm{P}$ & Poverty & $\begin{array}{l}\text { Competent, massive- to medium-bedded gray } \\
\text { limestone strikes } \mathrm{N} .55^{\circ} \mathrm{W} \text {., dips } 40^{\circ} \mathrm{NE} \text {. } \\
\text { An area of secondary limonite-hematite } \\
\text { stained limestone is } 5 \mathrm{ft} \text { thick, } 20 \mathrm{ft} \\
\text { long, and } 20 \mathrm{ft} \text { deep. }\end{array}$ & $\begin{array}{l}\text { One pit and a } 22-f t \text {-deep } \\
\text { inclined shaft. }\end{array}$ & $\begin{array}{l}\text { Two select and three chip samples from the } \\
\text { iron-stained lens contained no significant } \\
\text { values. }\end{array}$ \\
\hline $3 \mathrm{P}$ & Ellen group & $\begin{array}{l}\text { Blocky, tron-stained limestone with dark gray } \\
\text { chert nodules has minor interbeds of red to } \\
\text { green shale. The property was located for } \\
\text { talc in } 1952 \text {. }\end{array}$ & $\begin{array}{l}\text { Several bulldozer cuts and } \\
\text { two prominent } 100-\mathrm{ft}-\mathrm{long} \\
\text { by } 50-\mathrm{ft} \text {-high bench cuts. }\end{array}$ & $\begin{array}{l}\text { Seven chip or grab samples from limestone and } \\
\text { shale contained no talc. }\end{array}$ \\
\hline $4 \mathrm{P}$ & $\frac{\text { Bouge Canyon }}{\text { area }}$ & $\begin{array}{l}\text { Red-brown shale with scattered calcte veins } \\
\text { and veinlets } 0.2 \text { to } 0.7 \text { ft thick } 1 \text { n contact } \\
\text { with massive gray } 11 \text { mestone. The rocks } \\
\text { strike N. } 55^{\circ} \mathrm{W} \text {. and dip } 30^{\circ} \text { to } 35^{\circ} \mathrm{NE} \text {. }\end{array}$ & $\begin{array}{l}\text { Three small pits and a } \\
\text { caved adit estimated to } \\
\text { be less than } 50 \mathrm{ft} \text { long. }\end{array}$ & $\begin{array}{l}\text { One chip and four grab samples contained no } \\
\text { significant values. }\end{array}$ \\
\hline 5P & $\frac{\text { Robinson }}{\text { Canyon area }}$ & $\begin{array}{l}\text { Massive limonite-statned cherty limestone is } \\
\text { locally brecciated. }\end{array}$ & $\begin{array}{l}\text { A } 34-f t-1 \text { ong trench, and } \\
\text { a pit. }\end{array}$ & Three samples contained no significant values. \\
\hline $6 \mathrm{P}$ & $\frac{\text { Laurin Canyon }}{\underline{\text { area }}}$ & $\begin{array}{l}\text { Pink-red quartzite 1nterbedded with buff-colored } \\
1 \text { lmestone strikes northwest and dips } 50^{\circ} \text { to } \\
70^{\circ} \mathrm{NE} \text {. }\end{array}$ & $\begin{array}{l}\text { One } 13-f t-1 \text { ong adit and } \\
\text { a } 60-\mathrm{ft}-\text { long trench. }\end{array}$ & $\begin{array}{l}\text { One chip and two grab samples contained no } \\
\text { significant values. }\end{array}$ \\
\hline $7 \mathrm{P}$ & $\frac{\text { Porier Canyon }}{\text { area }}$ & $\begin{array}{l}\text { Incompetent, massive, buff-colored limestone with } \\
\text { hairline fracture fillings of manganese. The } \\
\text { extent of the manganese could not be determined } \\
\text { beyond pit limits. }\end{array}$ & Two shallow pits. & $\begin{array}{l}\text { One chip and two grab samples contained } \\
0.05 \%, 0.15 \% \text {, and } 0.13 \% \text { manganese, } \\
\text { respectively. }\end{array}$ \\
\hline
\end{tabular}


$8 \mathrm{P}$ $\frac{\text { Unknown }}{(14,6,5)}$

$9 \mathrm{P}$

Morning Star

$10 \mathrm{P}$

Copper Queen-

Rattlesnake Lod

$11 \mathrm{P}$

$\frac{\text { Lance Nos. } 1}{\text { and } 2}$

$12 \mathrm{P}$
Decomposed tan-brown dolomite with halrline fracture fillings of 1 monte and manganese. The 2.3-ft thick lens could not be traced beyond pit $11 \mathrm{mits}$.

Limestone strikes N. $10^{\circ}$ W. and dips $30^{\circ}-35^{\circ}$ NE. A $10-\mathrm{ft}$ by $30-\mathrm{ft}$ outcrop has numerous closely-

A 1 - to 2-ft-thick shear zone strikes N. $70^{\circ} \mathrm{W}$. and dips $26^{\circ}$ to $36^{\circ}$ SW for about 100 ft along a dolomite-quartzlte unconformity. The shear zone is comprised of gouge, calcite veins, limonite, quartz lenses, and at one location,
malachite stains.

A 20-ft-thick band of quartz-magnetite iron formation strikes $\mathrm{N} .45 \mathrm{~W}$. and dips southwest and is partly exposed for $700 \mathrm{ft}$ in decomposed chise and gnelss. This is part of the deposit.

Precambrian gneiss, schist, and bands of quartzmagnetite iron-formation are folded into an east-southeast plunging syncline. A $1,000-f$ by $4,000-f t$ upward-faulted trough section contains the most highly contorted and thickest ( 100 to $300 \mathrm{ft}$ ) 1ron-formation bands. Results from two drill holes in this area averaged $34 \%$ fron to a depth of $500 \mathrm{ft}$ (James and Wier. 1972).
One shallow pit.

None.

Two adits, 26 and $40 \mathrm{ft}$ long, and six shallow pits.

One shallow pit.

Seven closely spaced 100 ft to 400 tt lon and $\mathrm{from} 2$ to $10 \mathrm{ft}$ deep. and one pit.
One chip and one grab sample each contained $0.22 \%$ manganese.

One grab sample contained no significant values.

A total of nine chip samples were taken across the shear zone. Three from the 40-f $t$ adit contained $0.06 \%, 0.07 \%$, and $0.04 \%$ copper. One other chip sample contained $4.2 \%$ zinc.

A random chip and a grab sample assayed $32.2 \%$ and 9.5\% Iron, respectively.

Twenty-two random chip or grab samples ranged from $9.3 \%$ to $37.5 \%$ iron, but averaged $22.1 \%$ then. The trough section has over one-half of 0.5 million sa ft. If iron- and covers over these exposures are consistent to a band $500 \mathrm{ft}, 32$ million cons of sutecon 1/ Several properties listed as "unknown" could not be identifled by clalm notices or through published reports. The numbers in parentheses following "unknown"
represent locations by section, township, and range.

Underlined names indicate properties inside the study area. (From Schmauch, 1985) 
Concurrent with faulting and differential displacement across the faults, the mountains were eroded, and some of the material was preserved locally as the coarse clastics of the Beaverhead Group. Later during deposition of the Beaverhead, quartzite and siltite clasts (pebbles and cobbles) from the Proterozoic Belt Supergroup flooded in from the west and are preserved in the youngest strata of the Beaverhead within the Ruby Range. The final stage of the orogeny is recorded in the placement of discrete blocks of Archean and Paleozoic strata along the west, north, and to a lesser extent, the east flank of the northern third of the Ruby Range. These blocks were interpreted as gravity slide blocks by Tysdal $(1970,1976 a)$, although Schmidt and Garihan (1983, map p. 274) interpreted a few of those along the western side of the mountains as thrust slices. The northern part of the range is flanked by Tertiary normal faults, which separate the mountains from the basins.

\section{Description of Rock Units}

Rock units within or immediately adjacent to the wilderness study area are described below, with letter symbols as shown on plate 1. Descriptions of the Archean (older than 2,500 m.y.) rock units are adapted from James and Wier (1972) and Karasevich (1980, 1981); descriptions of the younger units are from Tysdal (1976a, b). No relative age is implied by the order of the Archean rock units.

Archean quartzofeldspathic gneiss (Agn)-Most widespread unit is well foliated, medium- to coarsegrained gneiss. The light-colored variety is chiefly a quartz-orthoclase-plagioclase rock. The medium- to darkcolored varieties are composed of quartz-plagioclasebiotite or quartz-plagioclase-biotote-hornblende assemblages. Common accessory minerals include garnet, zircon, and apatite.

Archean marble (Am)-White, tan, pale-green, and brown dolomitic and calcitic marble that is fine to coarse grained. Layering is well defined by thin seams of quartz; by accessory minerals such as tremolite, pyroxene, biotite, muscovite, or graphite; or by differences in the iron content of the marble. Forms units as much as $3,000 \mathrm{ft}$ thick.

Archean amphibolite (Aa)-Dark-green to black hornblendic gneiss that commonly forms lenses and pods a few tens of feet thick. Minor or accessory minerals include clinopyroxene, biotite, apatite, and zircon. Near the iron-formation adjacent to the southeast corner of the wilderness study area, gneissic amphibolite contains abundant pyroxene.

Archean ultramafic rock (Ac)-Dark-green to black, fine- to coarse-grained metapyroxenite and metaperidotite in which the pyroxene and olivine are extensively altered. Occurs only in area of iron-formation.
Archean iron-formation (Ai)—Dark-colored, fine- to medium-grained, well-layered rock composed of magnetite, quartz, and minor garnet and clinopyroxene. Beds as thick as several tens of feet. Present only adjacent to the southeast corner of the wilderness study area.

Undivided sedimentary rocks of Cambrian age $(€ u)-C h i e f l y$ limestone and dolomite, with lesser shale and sandstone. In descending order: the Red Lion Formation is mainly light-brown dolomite, with domal and columnar stromatolites in the uppermost part; thickness 115$170 \mathrm{ft}$. The Pilgrim Dolomite is brown, thin- to mediumbedded dolomite, except for crossbedded quartz sandstone in the uppermost few feet of the formation. The Park Shale is olive-green clay shale; $150-200 \mathrm{ft}$ thick. The Meagher Limestone is light-gray, thin-bedded limestone, except where it has been dolomitized and is now pale yellowish brown; it ranges from about 550 to $750 \mathrm{ft}$ thick. The Wolsey Shale is olive-green finely micaceous clay shale and siltstone; it is $60-100 \mathrm{ft}$ thick. The Flathead Sandstone consists of light-colored, fine- to coarse-grained quartz sandstone; about $60 \mathrm{ft}$ thick; unconformably overlies the Archean metamorphic rocks.

Undivided sedimentary rocks of Mississippian and Devonian age $(M D u)-C h i e f l y$ limestone and dolomite. The upper part is the Devonian and Mississippian Three Forks Formation, which consists of an upper member of grayish-orange siltstone; a middle member of olive-green clay shale; and a lower member of light-gray, thin- to thick-bedded limestone. Total thickness of the Three Forks is about $150 \mathrm{ft}$. The underlying Jefferson Dolomite is yellowish-brown, medium- to thick-bedded, dense, fetid dolomite, which is about $250 \mathrm{ft}$ thick.

Undivided sedimentary rocks of Mississippian age $(\mathrm{Mu}$-Mainly limestone. The Kibbey(?) Formation, at the top of the sequence, is brick-red, thin- to medium-bedded dolomite, silty dolomite, and siltstone. The top of the Kibbey(?) has been eroded, but the remaining rocks range from about 20 to $140 \mathrm{ft}$ thick. The Mission Canyon Limestone is light-gray-weathering, medium- and thick-bedded cliff-forming limestone, which contains evaporite-solution breccia zones in the upper part and chert stringers in the lower part. The formation is about $1,400 \mathrm{ft}$ thick. The upper half of the underlying Lodgepole Limestone is lightgray, medium- to thick-bedded limestone that is abundantly fossiliferous; the lower half of the formation is yellowish-brown thin-bedded argillaceous limestone. Total thickness of the Lodgepole is about $600 \mathrm{ft}$.

Beaverhead Group of Cretaceous age $(\mathrm{Kb})-$ Reddish-orange conglomerate composed of well-rounded cobbles of quartzite and siltite clasts eroded from the Proterozoic Belt Supergroup; cobbles and boulders of limestone eroded from Paleozoic formations; and clasts derived from metamorphic rocks of the range. The group is preserved in isolated outcrops on the west side of the range. Total thickness as much as $150 \mathrm{ft}$. 
Volcanic rocks of Tertiary age (Tv)-Dark-colored andesitic tuff breccia, lapilli tuff, and agglomerate that is crudely bedded and contains well-rounded andesite clasts. The unit is preserved only in one place along the west side of the wilderness study area.

Intrusive rocks of Tertiary age (Tib, Tia, Tir)-Sills and pipelike intrusive bodies of basalt, and less commonly of andesite and rhyolite, chiefly along the west flank of the range.

Bozeman Group of Tertiary age $(T b)$-Conglomerate. Along the western side of the range, the upper part of the unit is composed mainly of quartzite clasts; along the east flank it is composed of clasts eroded from Paleozoic formations. The lower part of the group is olive to gray tuffaceous mudstone, siltstone, and sandstone. Total thickness is several hundred feet.

Sediments of Quaternary age ( $Q u)$-Alluvium, alluvial fans, colluvium, landslide deposits, and glacial deposits.

\section{Geochemistry}

\section{Sampling and Analytical Methods}

Stream-sediment samples were collected from most active first order (unbranched) drainages in the wilderness study area, as well as from all second order and larger streams. At each site a composite sample of fine detritus was taken from several places within the stream and later air dried for sieving and analysis. Heavy-mineral concen trates of stream sediments were collected near the streamsediment site, but were derived from coarser material thought to represent a relatively high-energy depositional environment. The heavy-mineral concentrates were obtained by panning; the samples were sent to the laboratory for drying and analysis.

Rock samples were collected to (1) identify and evaluate places where obvious mineralized or altered rock existed within the wilderness study area, and (2) determine background abundances of elements to help evaluate the stream-sediment samples. The samples usually were taken as representative composites of rock chips from outcrops, but the most mineralized or altered rocks were collected preferentially in some cases.

All samples were analyzed semiquantitatively for 31 elements using a six-step, direct-current arc, opticalemission, spectrographic method (Grimes and Marranzino, 1968). Stream-sediment samples were sieved through an 80-mesh (177 micron) screen, and a split of the portion passing through the sieve was analyzed. A split of each crushed and finely ground rock sample, and a small split of each heavy-mineral concentrate sample, were analyzed by this method. Atomic absorption analyses for gold were made on the remainder of each heavy- mineral concentrate sample, using the method of Thompson and others (1968). Rocks were analyzed for antimony, arsenic, bismuth, cadmium, and zinc using the atomic-absorption method of Viets and others (1984), in which the readily soluble portion of these elements is dissolved and analyzed; and for gold using the method of Thompson and others (1968).

\section{Results of Study}

Stream-sediment samples locally show values of chromium or nickel that are anomalous for the limestone terrane across which the streams flow. Heavy-mineral concentrate samples from these and a few other sites contain elevated values of manganese, nickel, chromium, and locally, cobalt. These elements form a suite common in mafic or ultramafic rocks, and most of the sediments probably were derived in part from basalt intrusives present locally within the limestone terrane. At Spring Canyon in the northwestern part of the wilderness study area, the likely sources of this suite of elements in the streams are the tiny pipelike basalt bodies that intruded the Beaverhead Group. Analysis of the basalt (table 4, sample no. 84MTz132) shows elements of this suite. In the limestone terrane of Laurin Canyon, in the east-central part of the wilderness study area, the elevated values in concentrate samples are from streams that have small basaltic intrusive bodies in their upper reaches. At the mouth of the limestone-bearing Porier Canyon, concentrate sample $14 S$ (table 3 ) has elevated values of chromium and manganese for which no immediate source is known; the values probably reflect an unmapped basaltic intrusive body in the drainage.

At Dry Creek, on the western edge of the wilderness study area, concentrate samples $1 \mathrm{~S}$ and $26 \mathrm{~S}$ (table 3 and pl. 1) contain values of manganese that are slightly elevated for a limestone terrane. No mafic intrusive bodies are known in the immediate area of the sample sites. However, the streams of this area cross amphibolitebearing Archean metamorphic rocks within 1-3 mi of the sample sites; the values are not anomalous for Archean rocks. At the southern edge of the wilderness study area, manganese, nickel, and chrome in sample $18 \mathrm{~S}$ (table 3 and $\mathrm{pl}$. 1) are not considered anomalous for the crystalline rocks of the area. The values likely were derived from the several sill-like amphibolite bodies just upstream from the sample site.

A few concentrate samples from the western flank of the mountain range show some very low values for gold. The only known possible source of the element is conglomeratic strata of the Cretaceous Beaverhead Group. This formation is in part composed of clastic materials eroded from the Proterozoic Belt Supergroup, and the conglomeratic strata are known to contain traces of gold throughout the outcrop area in southwestern Montana. The 
Table 2. Semiquantitative spectrographic analyses of

[N. M. Conklin, L. A. Bradley, and M. J. Malcolm, analysts, Branch of Analytical Chemistry. Analyses in ppm except where shown in at midpoints $10,7,5,3,2,1.5,1$, anfd so forth]

\begin{tabular}{|c|c|c|c|c|c|c|c|c|c|c|c|c|c|c|}
\hline $\begin{array}{l}\text { Location } \\
\text { Number }\end{array}$ & $\begin{array}{l}\text { Sample } \\
\text { Number }\end{array}$ & $\begin{array}{l}\text { Latitude } \\
\text { deg-min-sec }\end{array}$ & $\begin{array}{l}\text { Longitude } \\
\text { deg-min-s ec }\end{array}$ & $\begin{array}{l}\mathrm{Fe} \% \\
(0.05)\end{array}$ & $\begin{array}{l}\mathrm{Mg} \% \\
(0.02)\end{array}$ & $\begin{array}{c}\mathrm{Ca} \% \\
(0.05)\end{array}$ & $\begin{array}{l}\mathrm{Ti} \% \\
(0.002)\end{array}$ & $\begin{array}{c}\mathrm{Mn} \\
(10)\end{array}$ & $\begin{array}{l}\mathrm{Ag} \\
(0.5)\end{array}$ & $\begin{array}{l}\text { As } \\
(700)\end{array}$ & $\begin{array}{c}\mathrm{Au} \\
(15)\end{array}$ & $\stackrel{\text { B }}{(10)}$ & $\begin{array}{c}\mathrm{Ba} \\
(30)\end{array}$ & $\begin{array}{l}\mathrm{Be} \\
(1)\end{array}$ \\
\hline is & RMO0 IAS & $45-19-47$ & $112-15-55$ & 1.5 & 7 & 7 & 0.15 & 3,000 & $\mathrm{~L}$ & L & L & 30 & 300 & 1 \\
\hline $2 \mathrm{~s}$ & RMO0 2AS & $45-21-32$ & $112-14-54$ & 1.5 & 1.5 & 3 & .15 & 700 & $\mathrm{~L}$ & L & $\mathrm{L}$ & 70 & 300 & $\mathrm{~L}$ \\
\hline $3 \mathrm{~S}$ & RMO0 3AS & $45-21-45$ & $112-15-39$ & 1.5 & 2 & 7 & .15 & 700 & $\mathrm{~L}$ & $\mathrm{~L}$ & $\mathrm{~L}$ & 30 & 300 & $\mathrm{~L}$ \\
\hline $4 \mathrm{~S}$ & RM00 4AS & $45-22-26$ & $112-15-45$ & 1 & 1.5 & 10 & .15 & 500 & $\mathrm{~L}$ & L & $\mathrm{L}$ & 15 & 300 & $\mathrm{~L}$ \\
\hline $5 S$ & RMO05AS & $45-22-39$ & $112-14-42$ & 1.5 & 2 & 5 & .15 & 700 & $\mathrm{~L}$ & L & $\mathbf{L}$ & 70 & 300 & $\mathrm{~L}$ \\
\hline $6 S$ & RM00 6AS & $45-22-07$ & $112-12-00$ & 0.7 & 1.5 & 15 & .15 & 300 & $\mathrm{~L}$ & $\mathrm{~L}$ & $\mathrm{~L}$ & 30 & 150 & $\mathrm{~L}$ \\
\hline $7 \mathrm{~S}$ & RM007AS & $45-21-31$ & $112-11-38$ & .7 & 1.5 & 15 & .15 & 300 & $\mathrm{~L}$ & $\mathrm{~L}$ & $\mathrm{~L}$ & 70 & 200 & $\mathrm{~L}$ \\
\hline $8 \mathrm{~S}$ & RM00 8AS & $45-21-02$ & $112-11-28$ & 1 & 1.5 & 15 & .15 & 300 & L & L & $\mathrm{L}$ & 30 & 150 & L \\
\hline 9S & RM009AS & $45-18-08$ & $112-09-23$ & 1 & 7 & 7 & .15 & 500 & $\mathrm{~L}$ & $\mathrm{~L}$ & $\mathrm{~L}$ & 15 & 200 & L \\
\hline $10 \mathrm{~S}$ & RM0 10AS & $45-17-35$ & $112-09-32$ & 3 & 3 & 3 & .3 & 1,500 & $\mathrm{~L}$ & $\mathrm{~L}$ & $\mathrm{~L}$ & 30 & 200 & $\mathrm{~L}$ \\
\hline $11 \mathrm{~s}$ & RMO0 IGS & $45-19-42$ & $112-11-51$ & 1.5 & 1.5 & 2 & .3 & 500 & $\mathrm{~L}$ & $\mathrm{~L}$ & L & 50 & 300 & 1 \\
\hline $12 \mathrm{~S}$ & RMO0 2GS & $45-19-49$ & $112-11-45$ & 1.5 & 1.5 & 5 & .3 & 500 & $\mathrm{~L}$ & $\mathrm{~L}$ & $\mathrm{~L}$ & 70 & 200 & 1 \\
\hline $13 \mathrm{~s}$ & RM00 3GS & $45-19-50$ & $112-11-21$ & 1.5 & 3 & 3 & .15 & 1,000 & $\mathrm{~L}$ & $\mathrm{~L}$ & $\mathrm{~L}$ & 20 & 150 & $\mathrm{~L}$ \\
\hline $14 \mathrm{~S}$ & RM00 4GS & $45-19-24$ & $112-10-17$ & 1 & 1.5 & 5 & .15 & 1,500 & L & $\mathrm{L}$ & $\mathrm{L}$ & 30 & 200 & $\mathrm{~L}$ \\
\hline $15 \mathrm{~S}$ & RM005GS & $45-18-42$ & $112-09-57$ & 1.5 & 1.5 & 10 & .15 & 300 & L & $\mathrm{L}$ & $\mathbf{L}$ & 70 & 200 & $\mathrm{~L}$ \\
\hline $16 \mathrm{~S}$ & RM006GS & $45-18-28$ & $112-16-49$ & 1.5 & 3 & 7 & .15 & 300 & $\mathrm{~L}$ & $\mathrm{~L}$ & $\mathrm{~L}$ & 30 & 300 & 1 \\
\hline $17 \mathrm{~S}$ & RM007GS & $45-19-39$ & $112-17-29$ & .7 & 2 & 15 & .15 & 200 & $\mathrm{~L}$ & L & $\mathrm{L}$ & $\mathrm{L}$ & 200 & L \\
\hline $18 \mathrm{~S}$ & RM008GS & $45-17-46$ & $112-13-25$ & 5 & 5 & 3 & .3 & 1,000 & $\mathrm{~L}$ & $\mathrm{~L}$ & L & $\mathrm{L}$ & 300 & 1 \\
\hline $19 \mathrm{~S}$ & RM00 ILS & $45-19-49$ & $112-12-51$ & 1.5 & 7 & 7 & .15 & 300 & $\mathrm{~L}$ & $\mathrm{~L}$ & $\mathrm{~L}$ & 70 & 150 & $\mathrm{~L}$ \\
\hline $20 \mathrm{~S}$ & RMO0 2LS & $45-19-45$ & $112-12-53$ & 7 & 5 & 1.5 & .3 & 1,500 & $\mathrm{~L}$ & L & $\mathrm{L}$ & 30 & 150 & $\mathrm{~L}$ \\
\hline $21 \mathrm{~s}$ & RM00 3LS & $45-18-33$ & $112-11-05$ & 3 & 1 & 3 & .2 & 700 & $\mathrm{~L}$ & $\mathrm{~L}$ & $\mathrm{~L}$ & 30 & 300 & 1.5 \\
\hline $22 \mathrm{~S}$ & RM00 4LS & $45-18-39$ & $112-12-12$ & 2 & 0.7 & 10 & .15 & 700 & $\mathrm{~L}$ & $\mathrm{~L}$ & $\mathrm{~L}$ & 70 & 200 & 1 \\
\hline $23 \mathrm{~S}$ & RM005LS & $45-18-40$ & $112-12-11$ & 3 & 3 & 7 & .15 & 1,500 & $\mathrm{~L}$ & $\mathrm{~L}$ & $\mathrm{~L}$ & 20 & 200 & 1 \\
\hline $24 \mathrm{~S}$ & RM00 6LS & $45-18-52$ & $112-11-25$ & 3 & 3 & 3 & .15 & 700 & $\mathrm{~L}$ & L & $\mathrm{L}$ & 100 & 300 & 1.5 \\
\hline $25 \mathrm{~S}$ & RM001PS & $45-19-52$ & $112-15-53$ & 1.5 & 1.5 & 5 & .2 & 1,000 & $\mathrm{~L}$ & $\mathrm{~L}$ & $\mathrm{~L}$ & 70 & 300 & 1 \\
\hline $26 \mathrm{~S}$ & RMO0 2PS & $45-20-09$ & $112-16-18$ & 1.5 & 5 & 5 & .2 & 3,000 & $\mathrm{~L}$ & $\mathrm{~L}$ & $\mathrm{~L}$ & 30 & 300 & $\mathrm{~L}$ \\
\hline $27 \mathrm{~S}$ & RMOO 3PS & $45-20-54$ & $112-16-03$ & 1.5 & 3 & 3 & .15 & 500 & $\mathrm{~L}$ & $\mathrm{~L}$ & L & 70 & 300 & $\mathrm{~L}$ \\
\hline $28 \mathrm{~S}$ & RM00 4PS & $45-21-32$ & $112-16-18$ & 1.5 & 1.5 & 10 & .2 & 700 & $\mathrm{~L}$ & L & $\mathrm{L}$ & 70 & 300 & $\mathrm{~L}$ \\
\hline $29 \mathrm{~S}$ & RM005PS & $45-21-38$ & $112-14-46$ & 1.5 & 1.5 & 5 & .2 & 700 & $\mathrm{~L}$ & $\mathrm{~L}$ & $\mathrm{~L}$ & 70 & 300 & $\mathrm{~L}$ \\
\hline $30 \mathrm{~s}$ & RM006PS & $45-22-45$ & $112-14-39$ & 1.5 & 2 & 3 & .15 & 700 & $\mathrm{~L}$ & $\mathrm{~L}$ & $\mathrm{~L}$ & 70 & 200 & $\mathrm{~L}$ \\
\hline $31 \mathrm{~s}$ & RM007PS & $45-17-32$ & $112-09-44$ & 1.5 & 1.5 & 7 & .2 & 700 & L & $\mathrm{L}$ & $\mathrm{L}$ & 30 & 300 & L \\
\hline $32 \mathrm{~S}$ & RM00 8PS & $45-17-16$ & $112-09-01$ & 3 & 3 & 7 & .2 & 1,500 & $\overrightarrow{\mathrm{L}}$ & $\mathrm{L}$ & L & L & 150 & $\mathrm{~L}$ \\
\hline
\end{tabular}

gold-bearing samples are from streams that drain outcrop areas of the Beaverhead and areas from which the Beaverhead has been eroded.

A few rock samples show elevated values of arsenic, antimony, and zinc, elements commonly associated with precious metals (gold and silver). No measurable amount of precious metals were found in rocks of the area, however. Samples $4 R$, 5R, and 6R (table 4) reflect hydrothermal activity in and adjacent to silicified and (or) limonitic fracture zones in the vicinity of the Copper Queen-Rattlesnake prospect in Taylor Canyon (loc. 10P, pl. 1). USBM data for this prospect (table 1) show minor copper and some zinc, but no gold or silver. One streamconcentrate sample (loc. 9S, pl. 1) from this general area showed a very low gold value and probably reflects the same hydrothermal activity. Sample $8 R$ (table 4), from a small fracture zone in the Ruby Peak area, contains some zinc but no measurable amount of precious metals.

\section{Geophysics}

\section{Methods}

Gravity data within and in the vicinity of the wilderness study area consist of 160 measurements made by J. H. Hassemer using a LaCoste and Romberg geodetic gravimeter $G-2^{l}$. The principal facts for these gravity measurements are available in a report by Hassemer and Kaufmann (1986). Sixteen of the measurements were made within the boundary of the wilderness study area. All measurements are referenced to a gravity value at a base station in Dillon, Montana (Kaufmann and others, 1983), incorporated into the International Gravity Standardization Net 1971.

\footnotetext{
'Use of trade names is for descriptive purposes only and does not imply endorsement by the U.S. Geological Survey
} 
stream-sediment samples, Ruby Mountains study area

percent. Limit of determination shown in parentheses. L, less than such limit; >, greater than value shown. Data reported in 6-step classification,

\begin{tabular}{|c|c|c|c|c|c|c|c|c|c|c|c|c|c|c|c|c|c|c|c|}
\hline $\begin{array}{c}B 1 \\
(10)\end{array}$ & $\begin{array}{c}\mathrm{Cd} \\
(30)\end{array}$ & $\begin{array}{l}\text { Co } \\
\text { (5) }\end{array}$ & $\begin{array}{c}\mathrm{Cr} \\
(10)\end{array}$ & $\begin{array}{l}\mathrm{Cu} \\
(5)\end{array}$ & $\begin{array}{c}\mathrm{La} \\
(30)\end{array}$ & $\begin{array}{l}\text { Mo } \\
\text { (5) }\end{array}$ & $\begin{array}{c}\mathrm{Nb} \\
(20)\end{array}$ & $\begin{array}{l}\text { Ni } \\
\text { (5) }\end{array}$ & $\begin{array}{c}\mathrm{Pb} \\
(10)\end{array}$ & $\begin{array}{l}\text { Sb } \\
(100)\end{array}$ & $\begin{array}{l}\mathrm{Sc} \\
(5)\end{array}$ & $\begin{array}{c}\text { Sn } \\
(10)\end{array}$ & $\begin{array}{l}\mathrm{Sr} \\
(100)\end{array}$ & $\begin{array}{l}\mathrm{V} \\
(10)\end{array}$ & $\begin{array}{l}W \\
(50)\end{array}$ & $\begin{array}{c}Y \\
(10)\end{array}$ & $\begin{array}{l}\mathrm{Zn} \\
(200)\end{array}$ & $\begin{array}{c}\mathrm{Zr}_{\mathbf{r}} \\
(10)\end{array}$ & $\begin{array}{l}\text { Th } \\
(200)\end{array}$ \\
\hline L & $\mathrm{L}$ & 7 & 50 & 30 & 70 & $\mathrm{~L}$ & L & 20 & 30 & L & 15 & L & 150 & 70 & L & 30 & L & 200 & L \\
\hline $\mathrm{L}$ & $\mathrm{L}$ & 7 & 50 & 30 & 30 & $\mathrm{~L}$ & $\mathrm{~L}$ & 30 & 30 & L & 10 & $\mathrm{~L}$ & 200 & 70 & $\mathrm{~L}$ & 30 & L & 150 & L \\
\hline L & $\mathrm{L}$ & 10 & 150 & 50 & $\mathrm{~L}$ & L & $\mathrm{L}$ & 50 & 15 & L & 15 & L & 300 & 70 & $\mathrm{~L}$ & 20 & $\mathrm{~L}$ & 150 & $\overline{\mathrm{L}}$ \\
\hline $\mathrm{L}$ & L & 5 & 30 & 20 & L & L & L & 15 & 15 & L & 7 & L & 150 & 30 & L & 30 & L & 150 & $\mathrm{~L}$ \\
\hline $\mathrm{L}$ & $\mathrm{L}$ & 7 & 50 & 30 & 30 & $\mathrm{~L}$ & $\mathrm{~L}$ & 20 & 20 & $\mathrm{~L}$ & 7 & $\mathrm{~L}$ & 300 & 50 & $\mathrm{~L}$ & 30 & L & 150 & $\mathrm{~L}$ \\
\hline $\mathrm{L}$ & L & 5 & 30 & 15 & L & $\mathrm{L}$ & $\mathrm{L}$ & 15 & 10 & L & 7 & L & 300 & 30 & $\mathrm{~L}$ & 15 & L & 50 & L \\
\hline $\bar{L}$ & L & 7 & 30 & 15 & L & L & $\mathrm{L}$ & 30 & 10 & L & 7 & $\mathrm{~L}$ & 300 & 50 & L & 15 & $\mathrm{~L}$ & 70 & L \\
\hline$\vec{L}$ & $\overline{\mathrm{L}}$ & 7 & 30 & 10 & L & $\mathrm{L}$ & L & 15 & 10 & $\mathrm{~L}$ & 7 & L & 300 & 30 & $\mathrm{~L}$ & 15 & $\mathrm{~L}$ & 70 & $\mathrm{~L}$ \\
\hline $\mathrm{L}$ & L & 5 & 30 & 15 & L & $\mathrm{L}$ & L & 15 & 15 & L & 5 & L & 150 & 30 & L & 15 & $\mathrm{~L}$ & 150 & $\mathrm{~L}$ \\
\hline L & $\mathrm{L}$ & 10 & 100 & 30 & $\mathrm{~L}$ & $\mathrm{~L}$ & $\mathrm{~L}$ & 30 & 15 & $\overrightarrow{\mathrm{L}}$ & 7 & L & 150 & 70 & $\mathrm{~L}$ & 15 & $\mathrm{~L}$ & 70 & $\mathrm{~L}$ \\
\hline $\mathrm{L}$ & L & 7 & 50 & 30 & 30 & $\mathrm{~L}$ & $\mathrm{~L}$ & 20 & 15 & L & 7 & L & 150 & 30 & L & 30 & L & 200 & L \\
\hline L & L & 7 & 30 & 30 & L & L & L & 30 & 15 & L & 7 & 20 & 150 & 70 & L & 20 & L & 150 & $\mathrm{~L}$ \\
\hline L & L & 7 & 70 & 30 & L & $\mathrm{L}$ & L & 20 & 15 & $\overrightarrow{\mathrm{L}}$ & 7 & $\mathrm{~L}$ & 150 & 50 & L & 15 & L & 70 & $\mathrm{~L}$ \\
\hline L & L & 7 & 50 & 20 & L & L & L & 15 & 15 & L & 5 & L & 150 & 30 & L & 15 & $\mathrm{~L}$ & 70 & L \\
\hline $\mathrm{L}$ & L & 7 & 30 & 15 & L & $\mathrm{L}$ & L & 15 & 15 & L & 7 & $\mathbf{L}$ & 300 & 50 & L & 15 & L & 100 & L \\
\hline L & L & 7 & 30 & 15 & L & $\mathbf{L}$ & $\mathrm{L}$ & 15 & 15 & L & 7 & L & 300 & 50 & L & 15 & L & 150 & L \\
\hline $\mathrm{L}$ & L & $\mathrm{L}$ & 30 & 15 & L & L & L & 15 & L & L & 5 & L & 300 & 30 & $\mathrm{~L}$ & 10 & $\mathrm{~L}$ & 70 & L \\
\hline L & L & 20 & 300 & 70 & 150 & L & L & 150 & 15 & $\mathrm{~L}$ & 15 & L & 300 & 100 & L & 70 & $\mathrm{~L}$ & 300 & L \\
\hline $\mathrm{L}$ & $\mathrm{L}$ & 10 & 70 & 15 & $\mathrm{~L}$ & $\mathrm{~L}$ & L & 30 & 15 & L & 7 & L & 150 & 70 & L & 15 & L & 70 & L \\
\hline L & $\mathrm{L}$ & 20 & 150 & 30 & 150 & $\mathbf{L}$ & $\mathrm{L}$ & 70 & 15 & L & 30 & 10 & $\mathrm{~L}$ & 150 & $\mathrm{~L}$ & 50 & $L$ & 150 & L \\
\hline L & L & 7 & 70 & 30 & 70 & $\mathrm{~L}$ & L & 15 & 15 & L & 10 & L & 150 & 70 & $\mathrm{~L}$ & 30 & L & 200 & $\mathrm{~L}$ \\
\hline L & L & 7 & 100 & 30 & L & L & L & 15 & 15 & $\mathrm{~L}$ & 10 & $\overline{\mathrm{L}}$ & 300 & 100 & $\mathrm{~L}$ & 15 & $\mathrm{~L}$ & 70 & $\mathrm{~L}$ \\
\hline L & L & 15 & 150 & 30 & 50 & L & L & 30 & 15 & L & 15 & L & $\mathrm{L}$ & 100 & $\mathrm{~L}$ & 20 & L & 150 & $\overline{\mathrm{L}}$ \\
\hline L & L & 15 & 70 & 30 & 30 & L & L & 20 & 15 & L & 15 & L & 150 & 70 & L & 15 & L & 150 & L \\
\hline $\mathrm{L}$ & $\mathrm{L}$ & 7 & 70 & 30 & $\mathrm{~L}$ & $\mathrm{~L}$ & $\mathrm{~L}$ & 30 & 15 & $\mathrm{~L}$ & 7 & 15 & 300 & 70 & $\mathrm{~L}$ & 20 & L & 150 & $\begin{array}{l}\mathrm{L} \\
\mathrm{L}\end{array}$ \\
\hline L & L & 10 & 70 & 30 & L & $\mathrm{L}$ & $\mathrm{L}$ & 30 & 20 & L & 7 & 15 & 150 & 70 & $\mathbf{L}$ & 20 & $\mathrm{~L}$ & 100 & L \\
\hline $\mathrm{L}$ & L & 7 & 50 & 30 & L & $\mathrm{L}$ & L & 30 & 30 & L & 7 & 15 & 150 & 70 & $\mathrm{~L}$ & 15 & $\mathrm{~L}$ & 150 & $\mathrm{~L}$ \\
\hline L & $\mathrm{L}$ & 7 & 30 & 30 & L & $\mathbf{L}$ & L & 30 & 20 & $\mathrm{~L}$ & 7 & $\mathrm{~L}$ & 300 & 70 & $\mathrm{~L}$ & 20 & $\mathrm{~L}$ & 150 & $\mathrm{~L}$ \\
\hline $\mathrm{L}$ & L & 7 & 50 & 30 & $\mathrm{~L}$ & L & L & 20 & 15 & L & 7 & L & 200 & 70 & $\mathrm{~L}$ & 20 & L & 300 & $\overline{\mathrm{L}}$ \\
\hline L & L & 7 & 50 & 30 & L & L & L & 30 & 15 & $\mathrm{~L}$ & 7 & $\mathrm{~L}$ & 150 & 50 & $\mathrm{~L}$ & 20 & $\mathrm{~L}$ & 150 & L \\
\hline $\mathrm{L}$ & L & 7 & 70 & 30 & L & L & L & 30 & 15 & L & 7 & L & 200 & 70 & $\mathbf{L}$ & 20 & L & 100 & L \\
\hline L & L & 15 & 150 & 30 & $\mathrm{~L}$ & $\mathbf{L}$ & L & 70 & 10 & L & 15 & 15 & 150 & 70 & $\mathrm{~L}$ & 20 & L & 50 & L \\
\hline
\end{tabular}

Observed gravity was computed using calibration coefficients established by laboratory bench and mountain loop calibrations, and corrections for earth tide and instrumental drift were made using a computer program developed by $M$. W. Webring, R. R. Wahl, and G. I. Evenden of the USGS. Bouguer gravity anomalies with attendant terrain and earth curvature corrections, assuming a reduction density of $2.67 \mathrm{~g} / \mathrm{cm}^{3}$ (grams per cubic centimeter), were computed relative to theoretical gravity values derived for Geodetic Reference System 1967 (Woollard, 1979). Equations used in this gravity reduction are summarized in Cordell and others (1982) and are implemented in a computer program of R. H. Godson, USGS. Terrain corrections to a distance of $175 \mathrm{ft}$ (Hammer, 1939) from each measurement point (station) were visually estimated during the field work. Terrain corrections beyond $175 \mathrm{ft}$, and extending to a distance of 103 mi from each station, were computed using a modification of the method of Plouff (1977) and incorporating U.S. Department of Defense terrain data digitized at a 15second grid interval. Also included in the data base are 14 stations of Kaufmann and others (1983) and 12 stations from the U.S. Defense Mapping Agency file. For purposes of editing and display, gravity-station locations were projected to $\mathrm{x}-\mathrm{y}$ coordinates, and Bouguer gravityanomaly values corresponding to these points were gridded using a minimum curvature algorithm (Webring, 1981). The gridded anomaly data were subsequently contoured using an algorithm for splining under tension (Godson and Webring, 1982) and were machine plotted. The complete Bouguer anomaly map shown in figure 3 represents only part of the larger area surveyed.

The aeromagnetic-anomaly map (fig. 4) is an enlargement of part of a map of southwestern Montana and east-central Idaho (USGS, 1975) compiled from data acquired at a barometric elevation of $12,000 \mathrm{ft}$ along east- 
Table 3. Semiquantitative spectrographic and chemical analyses

[R. T. Hopkins, spectrographic analyst; M. A. Pokorny and T. A. Roemer, chemical analysts, Branch of Exploration Research. Analyses in determination; >, greater than value shown. Data reported in 6-step classification, at midpoints 10,7, 5, 3, 2, 1.5, 1, and so forth]

\begin{tabular}{|c|c|c|c|c|c|c|c|c|c|c|c|c|c|c|c|c|}
\hline $\begin{array}{l}\text { Location } \\
\text { Number }\end{array}$ & $\begin{array}{l}\text { Sample } \\
\text { Number }\end{array}$ & $\begin{array}{l}\text { Latitude } \\
\operatorname{deg}-m i n-s e c\end{array}$ & $\begin{array}{l}\text { Longitude } \\
\text { deg-min-sec }\end{array}$ & $\begin{array}{l}\mathrm{Fe} \% \\
(0.1)\end{array}$ & $\begin{array}{c}\mathrm{Mg} \mathrm{\%} \\
(0.05)\end{array}$ & $\begin{array}{l}\mathrm{Ca} \% \\
(0.1)\end{array}$ & $\begin{array}{l}\mathrm{Ti} \% \\
(0.005)\end{array}$ & $\begin{array}{c}\mathrm{Mn} \\
(10)\end{array}$ & $\begin{array}{l}\mathrm{Ag} \\
(1)\end{array}$ & $\begin{array}{l}\text { As } \\
(500)\end{array}$ & $\begin{array}{c}\mathrm{Au} \\
(20)\end{array}$ & $\begin{array}{c}\text { B } \\
(20)\end{array}$ & $\begin{array}{c}\mathrm{Ba} \\
(50)\end{array}$ & $\begin{array}{l}\mathrm{Be} \\
(2)\end{array}$ & $\begin{array}{c}\text { B1 } \\
(20)\end{array}$ & $\begin{array}{c}\mathrm{Cd} \\
(50)\end{array}$ \\
\hline is & RMOO 1AC & $45-19-47$ & $112-15-55$ & 7 & 5 & 10 & 1 & 5,000 & $\mathbf{N}$ & $\mathrm{N}$ & $\mathbf{N}$ & 100 & $\mathrm{~L}$ & $\mathrm{~L}$ & $\mathbf{N}$ & $\mathrm{N}$ \\
\hline $2 S$ & RMOO 2AC & $45-21-32$ & $112-14-54$ & 7 & 3 & 7 & 0.5 & 1,000 & $\mathrm{~N}$ & $\mathrm{~N}$ & $\mathrm{~N}$ & 70 & 300 & $\mathrm{~L}$ & $\mathrm{~N}$ & $\mathrm{~N}$ \\
\hline 35 & KMOO $3 \mathrm{AC}$ & $45-21-45$ & $112-15-39$ & 5 & 5 & 20 & .5 & 2,000 & $\mathrm{~N}$ & $\mathrm{~N}$ & $\mathrm{~N}$ & $\mathrm{~L}$ & 300 & $\mathrm{~L}$ & $\mathrm{~N}$ & $\mathrm{~N}$ \\
\hline $4 \mathrm{~S}$ & RMO0 4AC & $45-22-26$ & $112-15-45$ & 1.5 & 1 & 30 & .15 & 300 & $\mathrm{~N}$ & $\mathrm{~N}$ & $\mathrm{~N}$ & $\mathrm{~N}$ & $\mathrm{~N}$ & $\mathrm{~N}$ & $\mathrm{~N}$ & $\mathrm{~N}$ \\
\hline $5 \mathrm{~S}$ & RMO05AC & $45-22-39$ & $112-14-42$ & 3 & 5 & 20 & .2 & 500 & $\mathrm{~N}$ & $\mathrm{~N}$ & $\mathrm{~N}$ & 200 & 100 & 2 & $\mathrm{~N}$ & $\hat{N}$ \\
\hline $6 \mathrm{~S}$ & RMDO GAC & $45-22-07$ & $112-12-00$ & 1.5 & 1.5 & 30 & .15 & 300 & $\mathrm{~N}$ & $\mathbf{N}$ & $\mathrm{N}$ & 70 & $\mathrm{~L}$ & $\mathrm{~L}$ & N & $\mathrm{N}$ \\
\hline $7 \mathrm{~S}$ & RM007AC & $45-21-31$ & $112-11-38$ & 3 & 1.5 & 50 & .15 & 300 & $\mathbf{N}$ & $\mathrm{N}$ & $\mathrm{N}$ & 70 & 200 & $\mathrm{~N}$ & $\mathrm{~N}$ & $\mathrm{~N}$ \\
\hline $8 S$ & RMOO 8AC & $45-21-02$ & $112-11-27$ & 2 & 1.5 & 30 & .15 & 500 & $\mathrm{~N}$ & $\mathbf{N}$ & $\mathbf{N}$ & 70 & L & L & $\mathbf{N}$ & $\mathrm{N}$ \\
\hline $9 \mathrm{~S}$ & RM009AC & $45-18-08$ & $112-09-23$ & 3 & 5 & 20 & .15 & 1,500 & $\mathrm{~N}$ & $\mathrm{~N}$ & $\mathrm{~N}$ & 30 & 70 & $\mathbf{L}$ & N & $\mathrm{N}$ \\
\hline 105 & RMO $10 A C$ & $45-17-35$ & $112-09-32$ & 7 & 7 & 15 & .3 & 5,000 & $\mathrm{~N}$ & $\mathrm{~N}$ & $\mathrm{~N}$ & 50 & 50 & $\mathrm{~N}$ & N & $\mathbf{N}$ \\
\hline $11 \mathrm{~s}$ & RMOO 1GC & $45-19-42$ & $112-11-51$ & 10 & 3 & 3 & .5 & 3,000 & $\mathrm{~N}$ & $\mathrm{~N}$ & $\mathrm{~N}$ & 20 & L & $\mathrm{N}$ & $\mathrm{N}$ & $\mathbf{N}$ \\
\hline $12 \mathrm{~S}$ & $\mathrm{RMOO} 2 \mathrm{GC}$ & $45-19-49$ & $112-11-45$ & 2 & 5 & 20 & .15 & 1,000 & $\mathrm{~N}$ & $\mathbf{N}$ & $\mathbf{N}$ & 70 & $\mathbf{L}$ & $\mathbf{N}$ & N & $\mathrm{N}$ \\
\hline $13 \mathrm{~S}$ & RMO0 3GC & $45-19-50$ & $112-11-21$ & 5 & 5 & 10 & .3 & 2,000 & $\mathrm{~N}$ & $\mathrm{~N}$ & $\mathbf{N}$ & 50 & 50 & L & $\mathbf{N}$ & $\mathrm{N}$ \\
\hline $14 \mathrm{~S}$ & RMO0 4GC & $45-19-24$ & $112-10-17$ & 7 & 7 & 7 & .7 & 7,000 & $\mathrm{~N}$ & $\mathrm{~N}$ & $\mathrm{~N}$ & 20 & $\mathrm{~L}$ & $\mathrm{~L}$ & $\mathbf{N}$ & $\mathrm{N}$ \\
\hline $15 s$ & RMO05GC & $45-18-42$ & $112-09-57$ & 7 & 3 & 7 & .7 & 2,000 & $\mathrm{~N}$ & $\mathrm{~N}$ & $\mathbf{N}$ & 70 & 150 & L & $\mathrm{N}$ & N \\
\hline $16 S$ & RM00 6GC & $45-18-28$ & $112-16-49$ & 3 & 2 & 20 & .3 & 700 & $\mathrm{~N}$ & $\mathrm{~N}$ & $\mathbf{N}$ & 100 & 50 & L & $\mathbf{N}$ & $\mathbf{N}$ \\
\hline $17 \mathrm{~s}$ & RMO07GC & $45-19-39$ & $112-17-29$ & 7 & 2 & 15 & .7 & 2,000 & $\mathrm{~N}$ & $\mathrm{~N}$ & $\mathrm{~N}$ & 70 & 150 & $\mathrm{~N}$ & $\mathrm{~N}$ & N \\
\hline $18 \mathrm{~S}$ & RMD0 8GC & $45-17-46$ & $112-13-25$ & 15 & 2 & 3 & 2 & 5,000 & $\mathrm{~N}$ & $\mathrm{~N}$ & $\mathrm{~N}$ & $\mathbf{N}$ & $\mathrm{L}$ & $\mathrm{L}$ & $\mathbf{N}$ & N \\
\hline 195 & RMOO ILC & $45-19-49$ & $112-12-51$ & 20 & 3 & 3 & 2 & 7,000 & $\mathbf{N}$ & $\mathrm{N}$ & $\mathrm{N}$ & 30 & N & $\mathbf{N}$ & $\mathbf{N}$ & $\mathrm{N}$ \\
\hline $20 \mathrm{~s}$ & RMO0 2LC & $45-19-45$ & $112-12-53$ & 7 & 7 & 15 & .3 & 1,500 & $\mathbf{N}$ & $\mathrm{N}$ & $\mathrm{N}$ & 70 & $\mathrm{~L}$ & $\mathrm{~L}$ & $\mathrm{~N}$ & N \\
\hline 215 & RM00 3LC & $45-18-33$ & $112-11-05$ & 3 & 1.5 & 7 & .2 & 700 & $\mathbf{N}$ & $\mathbf{N}$ & $\mathbf{N}$ & 50 & 70 & I & $\mathrm{N}$ & $\mathrm{N}$ \\
\hline $22 S$ & RMO0 4LC & $45-18-39$ & $112-12-12$ & 5 & 3 & 5 & .5 & 3,000 & $\mathrm{~N}$ & $\mathrm{~N}$ & $\mathrm{~N}$ & 70 & 150 & $\mathrm{~L}$ & $\mathrm{~N}$ & $\mathrm{~N}$ \\
\hline $23 \mathrm{~S}$ & RM005LC & $45-18-40$ & $112-12-11$ & 7 & 3 & 3 & 1 & 3,000 & $\mathrm{~N}$ & $\mathrm{~N}$ & $\mathrm{~N}$ & 50 & $\mathrm{~L}$ & $\mathbf{N}$ & $\ddot{N}$ & $\mathrm{~N}$ \\
\hline $24 S$ & RMO0 6LC & $45-18-52$ & $112-11-25$ & 7 & 5 & 5 & .5 & 3,000 & $\mathrm{~N}$ & $\mathrm{~N}$ & $\mathrm{~N}$ & 50 & $\mathrm{~L}$ & $\mathrm{~L}$ & $\mathrm{~N}$ & $\ddot{N}$ \\
\hline $25 \mathrm{~S}$ & RMOO IPC & $45-19-52$ & $112-15-53$ & 7 & 2 & 7 & .5 & 5,000 & $\mathrm{~N}$ & $\mathrm{~N}$ & $\mathrm{~N}$ & 150 & 100 & $\mathrm{~L}$ & N & $\mathrm{N}$ \\
\hline $26 S$ & RMDO2PC & $45-20-09$ & $112-16-18$ & 5 & 5 & 15 & .2 & 5,000 & $\mathbf{N}$ & $\mathrm{N}$ & $\mathrm{N}$ & 100 & 150 & $\mathrm{~L}$ & $\mathrm{~N}$ & $\mathrm{~N}$ \\
\hline $27 \mathrm{~s}$ & RMOO 3PC & $45-20-54$ & $112-16=03$ & 2 & 5 & 15 & .15 & 500 & $\mathrm{~N}$ & $\mathrm{~N}$ & $\mathrm{~N}$ & 100 & 50 & 2 & $\mathrm{~N}$ & $\mathrm{~N}$ \\
\hline $28 \mathrm{~S}$ & $\mathrm{RMOO} 4 \mathrm{PC}$ & $45-21-32$ & $112-16-18$ & 1.5 & 1 & 20 & .15 & 500 & $\mathbf{N}$ & $\mathrm{N}$ & $\mathrm{N}$ & 50 & 70 & $\mathbf{N}$ & $\mathrm{N}$ & $\mathrm{N}$ \\
\hline $29 \mathrm{~S}$ & RM005PC & $45-21-38$ & $112-14-46$ & 5 & 1.5 & 10 & .5 & 700 & $\mathrm{~N}$ & $\mathrm{~N}$ & $\mathrm{~N}$ & 100 & 150 & $\mathrm{~N}$ & $\mathrm{~N}$ & $\mathrm{~N}$ \\
\hline $30 \mathrm{~s}$ & RMO0 6PC & $45-22-45$ & $112-14-39$ & 2 & 5 & 20 & .15 & 500 & $\mathrm{~N}$ & $\mathrm{~N}$ & $\mathrm{~N}$ & 100 & $\mathrm{~L}$ & $\mathrm{~L}$ & $\mathrm{~N}$ & $\mathrm{~N}$ \\
\hline $31 \mathrm{~s}$ & RM007PC & $45-17-32$ & $112-09-44$ & 3 & 5 & 20 & .15 & 2,000 & $\mathrm{~N}$ & $\mathrm{~N}$ & $\mathrm{~N}$ & 70 & 200 & L & $\mathrm{N}$ & $\mathbf{N}$ \\
\hline $32 \mathrm{~S}$ & RMOO 8PC & $45-17-16$ & $112-09-01$ & 15 & 5 & 5 & 1.5 & 7,000 & $\mathrm{~N}$ & $\mathbf{N}$ & $\mathrm{N}$ & $\mathrm{N}$ & L & $\mathbf{N}$ & $\mathrm{N}$ & $\mathbf{N}$ \\
\hline
\end{tabular}

west flight lines spaced approximately $2 \mathrm{mi}$ apart. The $1: 250,000$-scale map was optically enlarged to approximately 1:110,000 and anomalies were digitized by contour tracing. The digital data were then projected, gridded, and recontoured as described above.

Physical properties of four Archean rock typesmarble, biotite schist, talc schist, and iron-formationwere measured to determine whether their magnetizations or densities are sufficiently anomalous to serve as sources of magnetic and gravity anomalies. The marble is nonmagnetic but dense $\left(2.84 \mathrm{~g} / \mathrm{cm}^{3}\right)$. The biotite schist is very weakly magnetic (negligible remanent magnetization; induced magnetization of about $10^{-1} \mathrm{~A} / \mathrm{m}$ (amps per meter) and very dense $\left(3.65 \mathrm{~g} / \mathrm{cm}^{3}\right.$, although on the basis of other work nearby, this value may be much higher than average)). The talc schist is essentially nonmagnetic and somewhat dense $\left(2.76 \mathrm{~g} / \mathrm{cm}^{3}\right)$. The iron-formation is extremely magnetic (remanent magnetization of $10^{2} \mathrm{~A} / \mathrm{m}$; induced magnetization of $1.15 \times 10^{2} \mathrm{~A} / \mathrm{m}$ ) and very dense $\left(2.98 \mathrm{~g} / \mathrm{cm}^{3}\right)$. Thus, all of the Archean rock types sampled are expectedly dense and are candidate sources of gravity highs. However, only iron-formation is strongly magnetic and a candidate source of high-amplitude magnetic anomalies.

\section{Discussion of Anomalies}

The gravity anomaly map (fig. 3) is dominated by a broad high bordered by gradients that are conformable with margins of mapped rocks of the northern part of the Ruby Range (Tysdal, 1976a; Karasevich, 1981; Petkewich, 1972; Burfiend, 1967; and Kaufmann and Hanna, 1982). Within the wilderness study area, the high appears as a 10 -mgal circular enclosure that tapers southwestward to a small elliptical high in the vicinity of Beatch Canyon.

Steep gradients on the northeastern and northwestern flanks of the circular high, in the center of the wilder- 
of heavy-mineral concentrate samples, Ruby Mountains study area

ppm except where shown in percent; c, chemical. Limit of determination shown in parentheses. N, not detected; L, less than limit of

\begin{tabular}{|c|c|c|c|c|c|c|c|c|c|c|c|c|c|c|c|c|c|c|}
\hline $\begin{array}{c}\text { Co } \\
(10)\end{array}$ & $\begin{array}{c}\mathrm{Cr} \\
(20)\end{array}$ & $\begin{array}{c}\mathrm{Cu} \\
(10)\end{array}$ & $\begin{array}{c}\mathrm{La} \\
(50)\end{array}$ & $\begin{array}{c}\text { Mo } \\
(10)\end{array}$ & $\begin{array}{c}\mathrm{Nb} \\
(50)\end{array}$ & $\begin{array}{c}\mathrm{N} 1 \\
(10)\end{array}$ & $\begin{array}{c}\mathrm{Pb} \\
(20)\end{array}$ & $\begin{array}{l}\text { Sb } \\
(200)\end{array}$ & $\begin{array}{c}\mathrm{Sc} \\
(10)\end{array}$ & $\begin{array}{l}\text { Sn } \\
(20)\end{array}$ & $\begin{array}{l}\mathrm{S}_{\mathbf{r}} \\
(200)\end{array}$ & $\begin{array}{l}v \\
(20)\end{array}$ & $\begin{array}{c}W \\
(100)\end{array}$ & $\begin{array}{c}\mathrm{Y} \\
(20)\end{array}$ & $\begin{array}{l}\mathrm{Zn} \\
(500)\end{array}$ & $\begin{array}{c}\mathrm{Zr} \\
(20)\end{array}$ & $\begin{array}{l}\text { Th } \\
(200)\end{array}$ & $\begin{array}{c}\mathrm{Au} \\
\mathrm{c}(0.05)\end{array}$ \\
\hline 15 & 100 & 10 & 70 & N & $\mathrm{N}$ & 20 & 20 & $\mathrm{~N}$ & 15 & $\mathrm{~N}$ & $\mathrm{~N}$ & 150 & $\mathrm{~N}$ & 70 & $\mathrm{~N}$ & 500 & $\mathrm{~N}$ & L \\
\hline 20 & 200 & 30 & 50 & L & $\mathrm{N}$ & 70 & 70 & $\mathrm{~N}$ & L & $\mathrm{N}$ & 300 & 200 & $\mathrm{~N}$ & $\mathrm{~L}$ & $\mathrm{~N}$ & 70 & $\mathrm{~N}$ & $\mathrm{~N}$ \\
\hline 20 & 1,000 & 50 & L & $\mathrm{N}$ & $\mathrm{N}$ & 100 & 20 & $\mathrm{~N}$ & 10 & N & $\mathbf{N}$ & 200 & $\mathrm{~N}$ & L & $\mathrm{N}$ & 50 & N & N \\
\hline $\mathrm{N}$ & 30 & L & $\mathrm{L}$ & $\mathrm{N}$ & $\mathrm{N}$ & 10 & 30 & $\mathrm{~N}$ & $\mathrm{~N}$ & $\mathrm{~N}$ & N & 50 & $\mathrm{~N}$ & $\mathrm{~N}$ & $\mathrm{~N}$ & 300 & N & $\mathrm{N}$ \\
\hline $\mathrm{N}$ & 70 & 30 & $\mathrm{~L}$ & $\mathrm{~N}$ & $\mathrm{~N}$ & 20 & 30 & $\mathrm{~N}$ & $\mathrm{~N}$ & $\mathrm{~N}$ & $\mathrm{~N}$ & 70 & $\mathrm{~N}$ & $\mathrm{~L}$ & $\mathrm{~N}$ & 200 & $\mathrm{~N}$ & N \\
\hline $\mathrm{N}$ & 20 & 10 & L & $\mathrm{N}$ & N & 20 & 30 & $\mathrm{~N}$ & $\mathrm{~N}$ & $\mathrm{~N}$ & 500 & 30 & N & $\mathrm{N}$ & $\mathrm{N}$ & 20 & $\mathrm{~N}$ & $\mathrm{~N}$ \\
\hline N & 30 & 10 & N & $\mathbf{N}$ & N & 30 & L & $N$ & $\mathrm{~N}$ & N & 500 & 70 & $\mathrm{~N}$ & $\mathrm{~N}$ & $\mathrm{~N}$ & 50 & $\mathrm{~N}$ & $L$ \\
\hline $\mathrm{N}$ & 30 & 10 & N & $\mathrm{N}$ & $\mathrm{N}$ & 20 & L & $\mathrm{N}$ & $\mathrm{N}$ & $\mathrm{N}$ & 500 & 70 & N & $\mathrm{N}$ & $\mathrm{N}$ & 50 & $\mathrm{~N}$ & $\mathrm{~N}$ \\
\hline $\mathrm{N}$ & 70 & 10 & $\mathrm{~N}$ & $\mathrm{~N}$ & $\mathrm{~N}$ & 10 & 20 & $\mathrm{~N}$ & $\mathrm{~N}$ & $\mathbf{N}$ & $\mathrm{N}$ & 50 & $\mathrm{~N}$ & $\mathrm{~N}$ & $\mathrm{~N}$ & 50 & N & 0.05 \\
\hline 15 & 200 & 20 & $\mathrm{~N}$ & $\mathrm{~N}$ & $\mathrm{~N}$ & 50 & $\mathrm{~N}$ & $\mathrm{~N}$ & 20 & $\mathrm{~N}$ & $\mathrm{~N}$ & 150 & N & 30 & $\mathrm{~N}$ & 500 & $\mathrm{~N}$ & $\mathrm{~L}$ \\
\hline 20 & 300 & 15 & $\mathrm{~N}$ & $\mathrm{~N}$ & $\mathrm{~N}$ & 70 & L & $N$ & 20 & $\mathrm{~N}$ & $\mathrm{~N}$ & 150 & N & 50 & $\mathrm{~N}$ & 70 & N & N \\
\hline $\mathrm{N}$ & 50 & 10 & L & $\mathrm{N}$ & $\mathrm{N}$ & 20 & L & $\mathrm{N}$ & $\mathrm{N}$ & $\mathrm{N}$ & $\mathrm{L}$ & 50 & $\mathrm{~N}$ & $\mathrm{~N}$ & $\mathrm{~N}$ & 70 & $\mathrm{~N}$ & $\mathrm{~N}$ \\
\hline 10 & 100 & 15 & $\mathrm{~L}$ & $\mathrm{~N}$ & $\mathrm{~N}$ & 50 & N & N & L & $\mathrm{N}$ & $\mathrm{N}$ & 70 & $\mathrm{~N}$ & 50 & $\mathrm{~N}$ & 50 & $\mathrm{~N}$ & N \\
\hline 20 & 200 & 30 & 500 & $\mathrm{~N}$ & $\mathrm{~N}$ & 70 & 20 & $\mathrm{~N}$ & 20 & $\mathrm{~N}$ & N & 100 & N & 70 & $\mathrm{~N}$ & 1,500 & $\mathrm{~N}$ & $\mathrm{~N}$ \\
\hline 15 & 100 & $\mathrm{~L}$ & 70 & $\mathrm{~N}$ & $\mathrm{~N}$ & 50 & 20 & $\mathrm{~N}$ & 15 & $\mathrm{~N}$ & N & 150 & $\mathrm{~N}$ & 70 & $\mathrm{~N}$ & 500 & $\mathrm{~N}$ & $\mathrm{~N}$ \\
\hline $\mathrm{N}$ & 70 & 10 & $\mathrm{~N}$ & $\mathrm{~N}$ & $\mathrm{~N}$ & 30 & 20 & N & $\mathrm{N}$ & $\mathrm{N}$ & 500 & 70 & $\mathrm{~N}$ & L & $\mathrm{N}$ & 50 & $\mathrm{~N}$ & .1 \\
\hline L & 100 & L & 50 & $\mathrm{~N}$ & $\mathrm{~N}$ & 20 & 30 & $\mathrm{~N}$ & 15 & $\mathrm{~N}$ & $N$ & 100 & $\mathrm{~N}$ & 50 & $\mathrm{~N}$, & 1,500 & $\mathrm{~N}$ & $\mathrm{~N}$ \\
\hline 20 & 500 & 20 & 1,000 & $\mathrm{~N}$ & $\mathrm{~N}$ & 150 & 50 & $\mathrm{~N}$ & 30 & $\mathrm{~N}$ & N & 300 & $\mathrm{~N}$ & 500 & $\mathrm{~N}$ & 2,000 & $\mathrm{~N}$ & L \\
\hline 30 & 500 & 20 & 300 & $\mathrm{~N}$ & $\mathrm{~N}$ & 70 & L & $\mathrm{N}$ & 30 & $\mathrm{~N}$ & N & 300 & $\mathrm{~N}$ & 150 & $\mathrm{~N}$ & 500 & $\mathrm{~N}$ & $\mathrm{~L}$ \\
\hline 15 & 150 & 50 & $\mathrm{~N}$ & $\mathrm{~N}$ & N & 50 & 20 & $\mathrm{~N}$ & L & $\mathrm{N}$ & $\mathbf{N}$ & 70 & $\mathrm{~N}$ & 20 & $\mathbf{N}$ & 100 & $\mathrm{~N}$ & N \\
\hline L & 70 & 15 & 50 & N & $\mathrm{N}$ & 50 & 50 & $\mathrm{~N}$ & L & $\mathrm{N}$ & $\mathrm{N}$ & 70 & $\mathrm{~N}$ & L & $\mathrm{N}$ & 100 & $N$ & $\mathrm{~N}$ \\
\hline 20 & 200 & 15 & so & $\mathrm{N}$ & $\mathrm{N}$ & 70 & L & $\mathrm{N}$ & 30 & $\mathrm{~N}$ & $\mathrm{~N}$ & 100 & $\mathrm{~N}$ & 70 & $\mathrm{~N}$ & 150 & $\mathrm{~N}$ & $\mathrm{~N}$ \\
\hline 50 & 200 & 20 & 70 & $\mathrm{~N}$ & $\mathrm{~N}$ & 100 & $\mathrm{~N}$ & $\mathrm{~N}$ & 70 & $\mathrm{~N}$ & $\mathrm{~N}$ & 150 & $\mathrm{~N}$ & 100 & $\mathrm{~N}$ & 100 & $\mathrm{~N}$ & $\mathrm{~N}$ \\
\hline 20 & 200 & 15 & L & N & $\mathrm{N}$ & 70 & L & N & 30 & $\mathrm{~N}$ & $\mathrm{~N}$ & 100 & $\mathrm{~N}$ & 150 & $\mathrm{~N}$ & 300 & N & $\mathrm{N}$ \\
\hline 20 & 200 & 50 & 50 & $\mathrm{~N}$ & $\mathrm{~N}$ & 50 & 20 & $\mathrm{~N}$ & 50 & $\mathrm{~N}$ & N & 100 & $\mathrm{~N}$ & 50 & $\mathrm{~N}$ & 100 & $\mathrm{~N}$ & L \\
\hline 10 & 100 & 20 & 50 & $\mathbf{N}$ & $\mathrm{N}$ & 70 & 30 & $\mathrm{~N}$ & 10 & $\mathrm{~N}$ & L & 70 & $\mathrm{~N}$ & 50 & $\mathrm{~N}$ & 70 & $\mathrm{~N}$ & $\mathrm{~L}$ \\
\hline $\mathrm{N}$ & 30 & 20 & 50 & L & $\mathrm{N}$ & 50 & 50 & $\mathrm{~N}$ & $\mathrm{~N}$ & $\mathrm{~N}$ & $\mathrm{~N}$ & 70 & $\mathrm{~N}$ & $\mathrm{~N}$ & $\mathrm{~N}$ & 70 & $\mathrm{~N}$ & $\mathrm{~N}$ \\
\hline $\mathrm{N}$ & 50 & 10 & $\mathrm{~L}$ & $\mathrm{~N}$ & N & 15 & 20 & $\mathrm{~N}$ & N & $\mathrm{N}$ & L & 50 & $\mathrm{~N}$ & L & $\mathrm{N}$ & 70 & $\mathrm{~N}$ & $\mathrm{~N}$ \\
\hline $\mathrm{L}$ & 70 & 20 & 50 & $\mathrm{~N}$ & $\mathrm{~N}$ & 20 & 20 & $\mathrm{~N}$ & $\mathrm{~N}$ & $\mathrm{~N}$ & $\mathrm{~L}$ & 150 & $\mathrm{~N}$ & $\mathrm{~L}$ & $\mathrm{~N}$ & 150 & $\mathrm{~N}$ & .1 \\
\hline $\mathrm{N}$ & 50 & 20 & L & $\mathrm{N}$ & $\mathrm{N}$ & 15 & 20 & $\mathrm{~N}$ & $\mathrm{~N}$ & $\mathrm{~N}$ & L & 50 & $\mathrm{~N}$ & L & $\mathrm{N}$ & 100 & $\mathrm{~N}$ & L \\
\hline $\mathrm{N}$ & 100 & 10 & $\mathrm{~N}$ & $\mathrm{~N}$ & N & 20 & L & $\mathrm{N}$ & L & $\mathrm{N}$ & $\mathrm{N}$ & 70 & N & L & $\mathrm{N}$ & 70 & $\mathrm{~N}$ & L \\
\hline 50 & 700 & 20 & N & N & $\mathrm{N}$ & 150 & 20 & $\mathrm{~N}$ & 20 & $\mathrm{~N}$ & $\mathrm{~N}$ & 200 & $\mathrm{~N}$ & 50 & L & 150 & $\mathrm{~N}$ & L \\
\hline
\end{tabular}

ness study area, follow the outline of mapped rocks. The gradients are generated by the contrast between the lowdensity alluvium and underlying basin-fill deposits of the intermontane basins and the adjacent higher density folded Phanerozoic (Paleozoic and Mesozoic) rocks and Archean metamorphic rocks of the mountain range. The steepness of the gradients suggests that these contacts are within 15 degrees of vertical and thus are probably fault contacts. The steep gradient on the southwestern flank of the high is generated by low-density basin fill deposits in lateral contact with Archean metamorphic rocks.

The small elliptical gravity high in the Beatch Canyon area is associated with the Kelly iron deposit. This iron-formation consists primarily of magnetite-rich layers, thinner quartz-rich layers, and ferromagnesian silicates, indicating that the deposit is anomalously dense and magnetic. The absence of well-defined gradients along contacts of Phanerozoic sedimentary rocks and Archean metamorphic rocks in the southern part of the area shown on figure 3 is unexpected, although data are somewhat sparse in this region. This absence of gradients implies that the folded Phanerozoic rocks are underlain by Archean metamorphic rocks at shallow depth throughout the area of the figure.

The aeromagnetic anomaly map (fig. 4) is dominated by a 200 -gamma (nT, or nanoTesla) circular high centered over the area of the Kelly iron deposit, where a flight line fortuitously crossed this terrane. Gradients flanking this anomaly extend southwestward to the southwest corner of the map area of figure 4 , where part of another circular high is present; this high is possibly associated with concealed iron-formation in metamorphic rocks that are more than $5 \mathrm{mi}$ south of the wilderness study area. The oval 50-gamma low that broadly covers the northern extremity of the Ruby Range, including most of the wilderness study area, is an expression of the relatively nonmagnetic character of the Phanerozoic and Archean rocks; the low is not an expression of reversed rem- 
Table 4. Semiquantitative spectrographic and chemical analyses of rock samples, Ruby Mountains study area

\begin{tabular}{|c|c|c|c|c|c|c|c|c|c|c|c|c|c|c|c|c|c|}
\hline $\begin{array}{l}\text { Location } \\
\text { Number }\end{array}$ & $\begin{array}{l}\text { Sample } \\
\text { Number }\end{array}$ & $\begin{array}{c}\text { Lat1tude } \\
\text { deg-min-sec }\end{array}$ & $\begin{array}{c}\text { Long1tude } \\
\text { deg-min-sec }\end{array}$ & $\begin{array}{l}\text { Rock } \\
\text { Type }\end{array}$ & $\begin{array}{l}\mathrm{Fe} \% \\
(0.05)\end{array}$ & $\begin{array}{l}\text { Mg \% } \\
(0.02)\end{array}$ & $\begin{array}{c}\mathrm{Ca} \% \\
(0.05)\end{array}$ & $\begin{array}{c}\text { Ti \% } \\
(0.002)\end{array}$ & $\begin{array}{c}\mathrm{Mn} \\
(10)\end{array}$ & $\begin{array}{l}\mathrm{Ag} \\
(0.5)\end{array}$ & $\begin{array}{l}\text { As } \\
(700)\end{array}$ & $\begin{array}{l}\mathrm{Au} \\
\text { (15) }\end{array}$ & $\begin{array}{l}\text { B } \\
(10)\end{array}$ & $\begin{array}{l}\mathrm{Ba} \\
(30)\end{array}$ & $\begin{array}{l}\text { Be } \\
\text { (1) }\end{array}$ & $\begin{array}{l}\mathrm{Bi} \\
(10)\end{array}$ & $\begin{array}{c}\mathrm{Cd} \\
(30)\end{array}$ \\
\hline $\mathrm{IR}$ & $84 \mathrm{MTz} 130$ & $45-19-57$ & $112-15-49$ & Red siltstone & 1.5 & 0.7 & 15 & 0.3 & 200 & $\mathrm{~L}$ & $\mathrm{~L}$ & L & 50 & 1,500 & $\mathrm{~L}$ & $\mathrm{~L}$ & $\mathrm{~L}$ \\
\hline $2 \mathrm{R}$ & 84MTz 131 & $45-20-37$ & $112-16-11$ & Lapill1 tuff & 5 & 1.5 & 3 & .3 & 1,500 & $\mathrm{~L}$ & L & L & $\mathrm{L}$ & 2,000 & 1.5 & $\mathrm{~L}$ & $\mathrm{~L}$ \\
\hline $3 \mathrm{R}$ & 84MTz 132 & $45-21-35$ & $112-15-03$ & Basalt & 7 & 3 & 7 & .5 & 1,500 & $\mathrm{~L}$ & $\mathrm{~L}$ & $\mathrm{~L}$ & $\mathrm{~L}$ & 2,000 & 1 & $\mathrm{~L}$ & $\mathrm{~L}$ \\
\hline $4 \mathrm{R}$ & 84MTz234 & $45-17-43$ & $112-10-19$ & Limonitic marble & 0.7 & 7 & 15 & .01 & 3,000 & L & $\mathrm{L}$ & $\mathrm{L}$ & $\mathrm{L}$ & 70 & $\mathrm{~L}$ & $\mathrm{~L}$ & $\mathrm{~L}$ \\
\hline $5 \mathrm{R}$ & 84MTz 235 & $45-17-43$ & $112-10-07$ & Hematitic sandstone & 5 & .7 & 1.5 & .15 & 150 & $\mathrm{~L}$ & $\mathrm{~L}$ & & 70 & 300 & $\mathrm{~L}$ & $\mathrm{~L}$ & $\mathrm{~L}$ \\
\hline $6 \mathrm{R}$ & $84 \mathrm{MTz} 236$ & $45-17-37$ & $112-10-00$ & Oxidized sandstone & 1 & .15 & 2 & .05 & 70 & $\mathrm{~L}$ & $\mathrm{~L}$ & $\mathrm{~L}$ & 15 & 70 & $\mathrm{~L}$ & $\mathrm{~L}$ & $\mathrm{~L}$ \\
\hline $7 \mathrm{R}$ & NR17 & $45-19-22$ & $112-14-00$ & Limonitic marble & 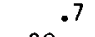 & 7 & 15 & L & 3,000 & $\mathrm{~L}$ & $\mathrm{~L}$ & $\mathrm{~L}$ & $\mathrm{~L}$ & 70 & $\mathrm{~L}$ & $\mathrm{~L}$ & $\mathrm{~L}$ \\
\hline $8 \mathrm{R}$ & NR40 & $45-18-22$ & $112-13-20$ & Limonitic quartzite & 20 & 1.5 & 0.7 & .15 & 1,500 & $\mathrm{~L}$ & $\mathrm{~L}$ & $\mathrm{~L}$ & $\mathrm{~L}$ & 150 & L & $\mathrm{L}$ & $\mathrm{L}$ \\
\hline $9 \mathrm{R}$ & RM001AR & $45-19-51$ & $112-16-04$ & Quartz pegmatite & .7 & 1.5 & 2 & $\mathrm{~L}$ & 700 & $\mathrm{~L}$ & $\mathrm{~L}$ & $\mathrm{~L}$ & $\mathrm{~L}$ & 20 & $\mathrm{~L}$ & $\mathrm{~L}$ & $\mathrm{~L}$ \\
\hline $10 \mathrm{R}$ & RM009PRA & $45-17-19$ & $112-09-25$ & Rusty quartz pegmatite & e .1 & .07 & .05 & .007 & 150 & $\mathrm{~L}$ & $\mathrm{~L}$ & $\mathrm{~L}$ & $\mathrm{~L}$ & 150 & $\mathrm{~L}$ & $\mathrm{~L}$ & L \\
\hline 10R & RM009PRB & $45-17-19$ & $112-09-25$ & Iron-formation & 20 & 2 & 1.5 & .07 & $>5,000$ & $\mathrm{~L}$ & $\mathrm{~L}$ & $\mathrm{~L}$ & $\mathrm{~L}$ & 500 & $\mathrm{~L}$ & L & $\mathrm{L}$ \\
\hline $10 \mathrm{R}$ & RM009PRC & $45-17-19$ & $112-09-25$ & Banded gneiss & 3 & 3 & 5 & .15 & 1,500 & $\mathrm{~L}$ & $\mathrm{~L}$ & $\mathrm{~L}$ & $\mathrm{~L}$ & 5,000 & L & L & $\mathrm{L}$ \\
\hline
\end{tabular}

\begin{tabular}{|c|c|c|c|c|c|c|c|c|c|c|c|c|c|c|c|c|c|c|c|c|c|c|c|c|}
\hline $1 R$ & $\mathrm{~L}$ & 70 & 7 & 70 & L & $\mathrm{L}$ & 7 & L & L & 7 & $\mathrm{~L}$ & 300 & 30 & L & 30 & L & 300 & L & L & L & 0.2 & L & 8 & L \\
\hline $2 R$ & 15 & 30 & 15 & 70 & L & L & 7 & 20 & L & 15 & L & 700 & 70 & L & 50 & L & 300 & L & L & L & L & L & 83 & $\overline{\mathrm{L}}$ \\
\hline $4 R$ & 5 & 10 & 5 & $\mathrm{~L}$ & $\mathrm{~L}$ & L & 20 & $\mathrm{~L}$ & $\mathrm{~L}$ & $\mathrm{~L}$ & $\mathrm{~L}$ & $\mathrm{~L}$ & 10 & $\begin{array}{l}\mathrm{L} \\
\mathrm{L}\end{array}$ & $\mathrm{L}$ & $\mathrm{L}$ & 70 & $\mathrm{~L}$ & $\begin{array}{r}18 \\
\end{array}$ & $\mathrm{~L}$ & 0.2 & 20 & 6 & $\mathrm{~L}$ \\
\hline $5 R$ & 10 & 100 & L & L & L & L & 30 & L & L & 7 & $\mathrm{~L}$ & 300 & 30 & L & 30 & L & 150 & L & 9 & L & 0.2 & 29 & 8 & L \\
\hline $6 R$ & 5 & L & $\mathrm{L}$ & L & $\mathrm{L}$ & L & 20 & L & L & 5 & $\mathrm{~L}$ & 150 & 15 & $\mathrm{~L}$ & $\mathrm{~L}$ & L & 70 & L & 23 & L & 0.1 & 39 & 22 & L \\
\hline $7 R$ & $\mathrm{~L}$ & $\mathrm{~L}$ & 70 & L & L & L & 7 & $\mathrm{~L}$ & L & L & $\mathrm{L}$ & $\mathrm{L}$ & L & $\mathrm{L}$ & $\mathrm{L}$ & L & $\mathrm{L}$ & $\mathrm{L}$ & 19 & $\mathrm{~L}$ & 0.2 & 11 & 5 & $\mathrm{~L}$ \\
\hline $10 R$ & 10 & 70 & 100 & L & L & L & 5 & L & L & 7 & L & L & 20 & L & L & L & 20 & L & L & $\mathrm{L}$ & 0.5 & L & 6 & - \\
\hline $10 \mathrm{R}$ & 20 & 500 & 70 & L & L & L & 150 & $\mathrm{~L}$ & $\mathrm{~L}$ & 15 & L & 150 & 70 & L & 10 & 300 & 70 & L & L & $\mathrm{L}$ & 0.1 & L & 52 & - \\
\hline
\end{tabular}


nant magnetization in metamorphic rocks. A weak high, forming a northwest-trending lineament on the southwest flank of this 50-gamma (nT) low, expresses a probable slight increase in magnetization of Archean rocks insufficient in volume to cause a corresponding gravity ridge. Likewise, local mapped occurrences of andesite, basalt, iron-formation, and serpentinized ultramafic rocks are insufficient in size to be detected by the widely spaced highaltitude flight lines.

\section{Mineral and Energy Resources}

Iron

The model (Kelly iron deposit).-Banded ironformation is a minor but widespread rock unit in the Archean metamorphic terrane of southwestern Montana. Iron-formation of the Kelly iron deposit exists within a tiny area of the southeastern part of the wilderness study area. The principal area of the Kelly deposit lies immediately adjacent to the southeast corner of the wilderness study area (in sec. 26, T. $6 \mathrm{~S}$., R. $5 \mathrm{~W}$., pl. 1). A thin (averaging about $30 \mathrm{ft}$ thick), oval-shaped belt of iron-formation nearly surrounds the principal part of the deposit; a small fraction of this thin belt occurs within the wilderness study area.

The Kelly deposit is an oxide facies iron-formation consisting chiefly of magnetite and quartz, with subordinate pyroxene and garnet. The iron-formation is dark gray to black, fine to medium grained, and streaky to well layered. It readily weathers into a reddish-brown soil. Iron-formation is associated with rocks that probably are of sedimentary origin-dolomite and clastics-and is inferred to have been a chemical sediment deposited in a shallow-water environment. The sequence was metamorphosed about 2,750 m.y. (James and Hedge, 1980) and underwent a second regional metamorphism about 1,600 m.y. (Giletti, 1966).

The Kelly deposit as mapped by James and Wier (1972) contains outcropping iron-formation and inferred iron-formation between outcrops as determined from trenches, a ground magnetometer survey, and from tracing the distribution of reddish-brown soil typical of weathered iron-formation. The layers of iron-formation are generally only a few feet thick, although in the principal area of the Kelly deposit layers are several tens of feet thick. The layers probably were of more uniform thickness when originally deposited, but they underwent pinching and swelling during deformation and associated metamorphism. Karasevich and others (1981) indicated that the metamorphic rocks in and near the Kelly deposit have undergone as many as four phases of folding.

Chemical analyses of two drill core samples from the Kelly deposit were reported by Bayley and James (1973, p. 954). The average composition (weight percent) for the oxides in the two cores was reported by James
(1981); the most abundant oxides are as follows: $\mathrm{Fe}_{2} \mathrm{O}_{3}$, 32.49; $\mathrm{FeO}, 19.05 ; \mathrm{SiO}_{2}, 39.79 ; \mathrm{MgO}, 2.43$; and $\mathrm{CaO}$, 1.88 .

The Kelly iron deposit did not produce a prominent geochemical signature in stream-sediment and heavy-mineral concentrate samples. As previously noted, the Kelly deposit is associated with a high-amplitude aeromagnetic high.

Resource potential.-The Kelly iron deposit is an identified resource that has the following characteristics: (1) outcrop of iron-formation, and (2) a prominent aeromagnetic and gravity high. In addition, the deposit was trenched and drilled by the Finlen and Sheridan Company in the 1950's.

Most layers of iron-formation of the Kelly deposit lie immediately adjacent to the southeast comer of the wilderness study area. At least one layer of iron-formation of the deposit extends into a tiny area of the southeasternmost part of the wilderness study area, near Taylor Canyon (northeasternmost part of sec. 26, T. 6 S., R. $5 \mathrm{~W}$., and southeastern corner sec. 24, T. 6 S. R. 5 W., pl. 1). This layer and its associated metamorphic rock are separated from the remainder of the wilderness study area by the South Fork fault (Kephart fault of Karasevich, 1980, 1981; and Karasevich and others, 1981) on the west, and on the north by an unnamed east-trending fault in Taylor Canyon.

Characteristics of the remainder of the area of outcropping Archean metamorphic rock within the wilderness study area were compared to those of the terrane of the Kelly deposit. With the exception of the tiny area described above, the metamorphic terrane within the boundaries of the wilderness study area lacks outcrops of ironformation, shows readily apparent source rock other than iron-formation for values of elements in stream-sediment and heavy-mineral concentrate samples, and is not characterized by gravity and magnetic anomalies normally associated with massive occurrences of iron-formation. This part of the wilderness study area is assigned a low potential for iron-formation, with a certainty level of $\mathrm{C}$ (available data gives a good indication of the level of mineral resource potential). The classification system used here is that of Goudarzi (1984), (see inside front cover) and is shown on plate 1 .

In the part of the wilderness study area where metamorphic terrane is concealed by younger sedimentary rocks, criterion 1 above cannot be evaluated because metamorphic rocks are not exposed to examination. However, with regard to criterion 2 , and in consideration of the flight height and spacing of the aeromagnetic survey and station spacing of the gravity survey, we may infer that no iron-formation deposit even a tenth the size or a tenth the magnetite content of the Kelly iron deposit occurs within the metamorphic rocks veneered by Mesozoic and Paleozoic rocks. The concealed area of metamor- 


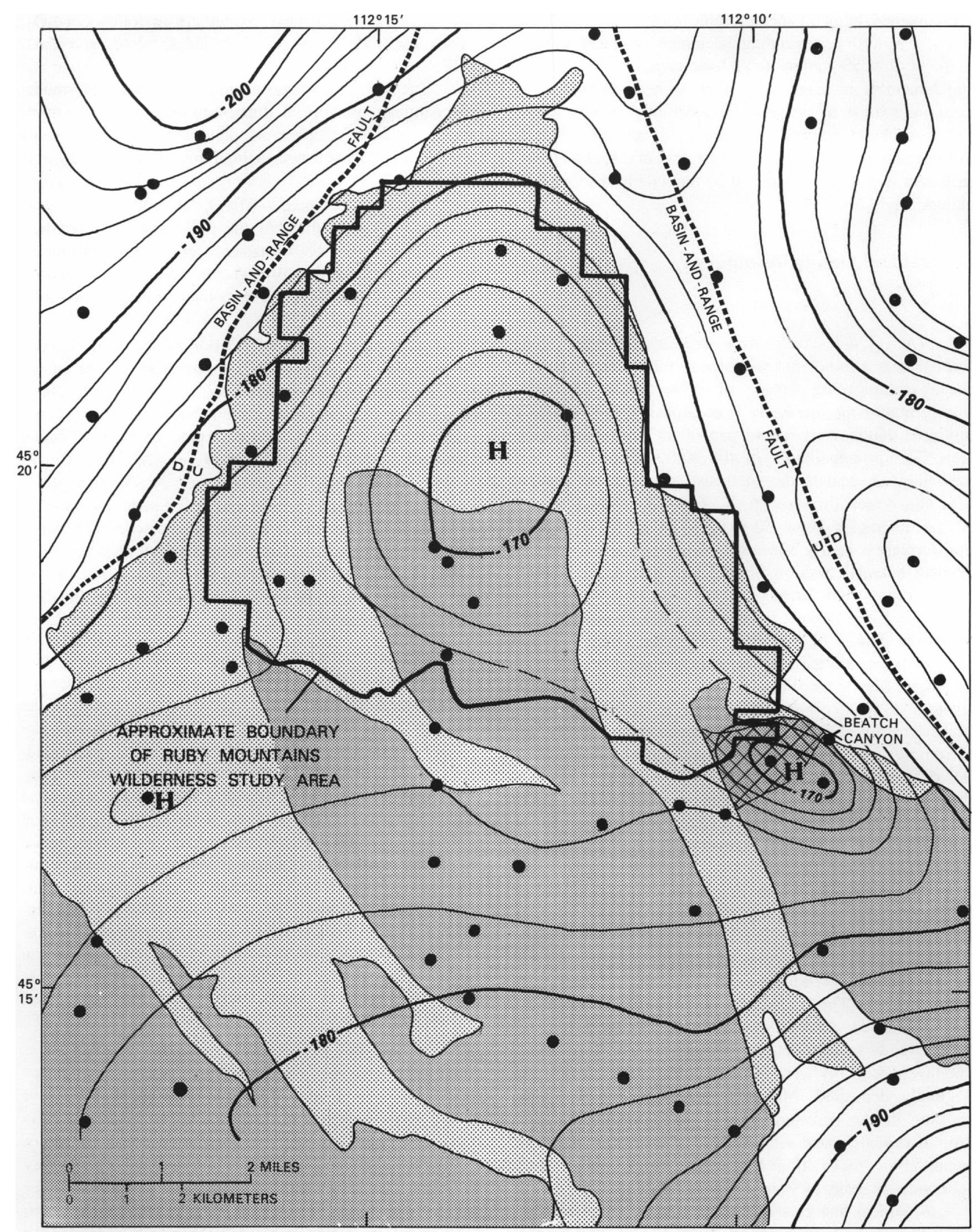

Figure 3 (above and facing page). Complete Bouguer gravity anomaly map and generalized geology in the vicinity of the Ruby Mountains study area. 


\section{EXPLANATION}

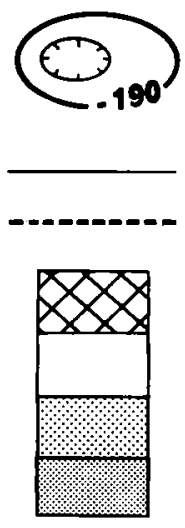

Gravity contours-Contour interval, 2 milligals; hachures indicate depression; dots show location of measurement stations; $\mathrm{H}$, gravity high

Contact

Normal fault, concealed-D, downthrown side; $\mathrm{U}$, upthrown side

Area of identified iron resources

Quaternary and Tertiary basin deposits

Mesozoic and Paleozoic sedimentary rocks

Archean metamorphic rocks

phic rock is judged to have a low resource potential for iron-formation, with a certainty level of B (available information suggests the level of mineral resource potential). Iron-formation in deposits very much smaller than that of the Kelly may exist beneath the sedimentary cover and not be detected by the existing aeromagnetic data; similarly, they could exist beneath the surface in areas of exposed Archean rocks.

Talc

By R. B. Berg

Montana Bureau of Mines and Geology

This section on mineral resource potential for talc is a summary of a contract study (Berg, 1987) carried out as a part of the USGS's evaluation of the mineral resource potential of the wilderness study area.

The model (talc in Archean marble). - Exposures of Archean marble were examined for talc; and soil, scree, and talus were searched for chips of talc and fragments of talc-bearing marble. Talc fragments can be readily recognized in the scree below inaccessible steep cliffs. In several places where talc chips were unusually abundant, the concentration of talc could be traced uphill to a source vein or pod. Although talc fragments are typically dark colored because of a coating of iron and manganese minerals, they are easily recognizable by their smooth surface and ease with which they can be scratched with the fingernail. The amount of discoloration of the talc fragments gives a crude indication of the distance that the talc has traveled from its source; in general, talc fragments less than several feet from their source are pale green and free of discoloration (Berg, 1987).

The concentration of talc occurrences within an area gives an indication of the likelihood for the occurrence of a significant deposit. As an example, in the Greenhorn Range (12 mi southeast of the wilderness study area), talc occurrences are much more abundant in the southern half of the range where the only talc mine in this range (inactive as of 1985) is situated. Berg (1979, sheets 2 and 3) showed 43 talc occurrences in the range, most of which are concentrations of talc chips in the soil. Although dolomitic marble is exposed throughout the Greenhorn Range, 33 of the 43 talc occurrences are in the southern part of the range. The density of talc occurrences in the southern part of the range is $2.2 / \mathrm{mi}^{2}$ of marble, whereas in the northern part of the range it is $0.7 / \mathrm{mi}^{2}$. No density concentrations were calculated for the entire wilderness study area of the Ruby Range, but in the parts of the wilderness study area rated as having high potential for talc, the density concentrations for talc occurrences are much greater than $2.2 / \mathrm{mi}^{2}$ (see pl. 1).

Host rock composition is the only recognized control of talc within the boundaries of the wilderness study area. Talc occurrences are limited to Archean marble, of which three varieties have been recognized in the wilderness study area. Type I marble, estimated to constitute 20 percent of the marble of the wilderness study area, is calcitic and contains no talc. Type II marble, estimated to make up 50 percent of the marble of the wilderness study area, consists of calcite, dolomite, and minor accessory minerals, and does not commonly contain talc. Type III marble, estimated to make up 30 percent of the marble of the wilderness study area, is dolomitic and contains most of the talc of the wilderness study area. (A detailed description of the characteristics of the three types of Archean marble is presented in Berg, 1987).

No evidence of structural control of talc occurrences was found in the wilderness study area. Quartz layers and boudins (lenses) up to about $1 \mathrm{ft}$ thick in the general area of Ruby Peak have been deformed locally into folds ranging from open to very tight (isoclinal), with the axial surfaces of the isoclinal folds subparallel to compositional layering of the enclosing marble. Folds are generally confined to individual compositional layers about 10 to 15 $\mathrm{ft}$ thick within the marble. Talc concentrations were not found to be controlled by these folds. No concentrations of talc were found near the high-angle faults that juxtapose Paleozoic sedimentary rocks against the Archean metamorphic rocks.

Talc is unknown in the dolomitic formations of $\mathrm{Pa}$ leozoic age in southwestern Montana, even though the dolomite would be an ideal host for the mineralizing solutions; this suggests that the talc formed during the Precambrian, after the metamorphic event of 2,700 m.y. Garihan (1973) suggested that talc formation can be correlated with the 1,600-m.y.-old thermal event that affected the metamorphic rocks of southwestern Montana.

An estimated 80 percent of the observed talc occurrences are within Type III marble, where the talc forms veinlets, small pods, and conformable layers. Veinlets range up to $1 / 2$ in. thick and are scattered throughout the 


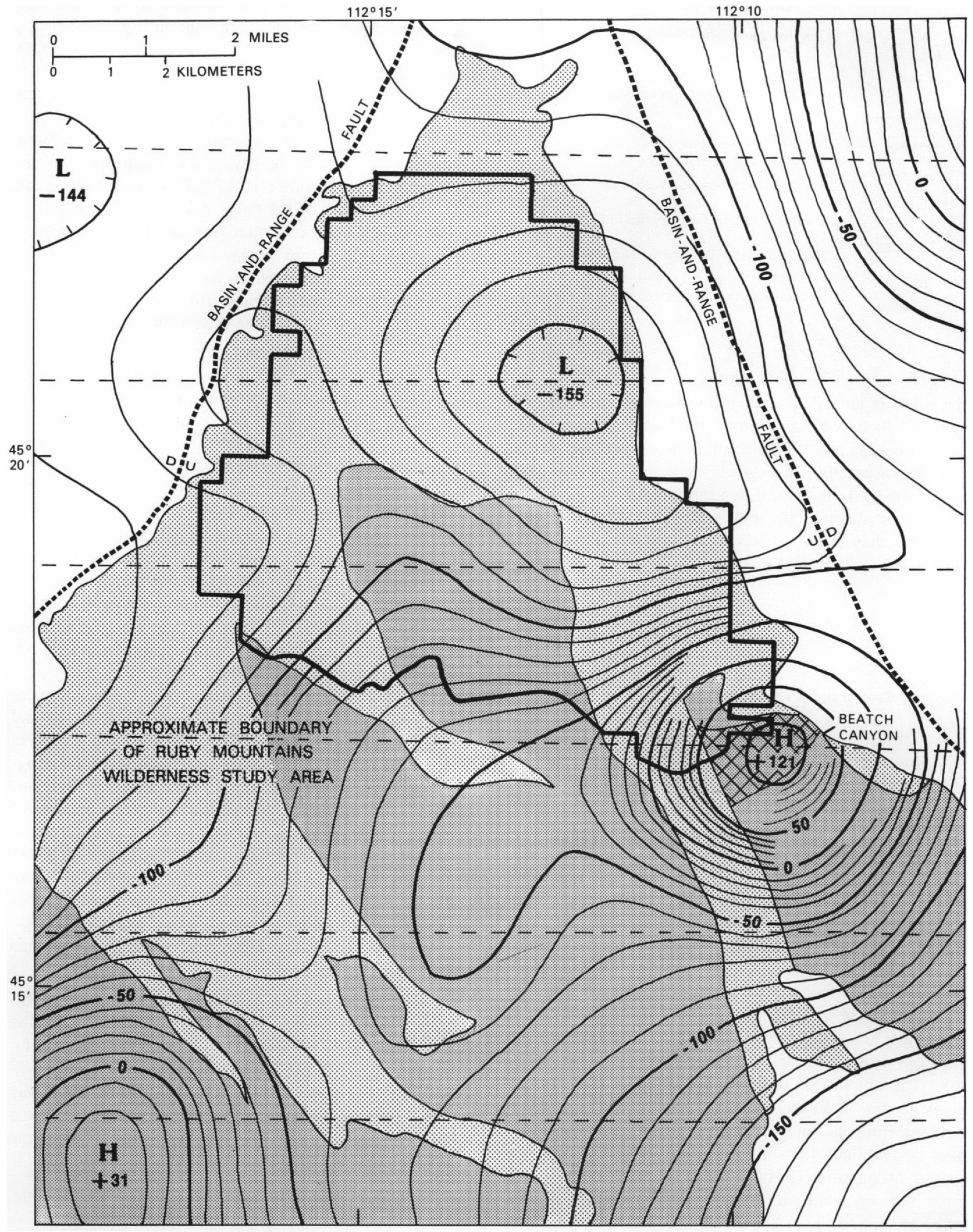

Figure 4 (above and facing page). Aeromagnetic anomaly map and generalized geology in the vicinity of the Ruby Mountains study area. 


\section{EXPLANATION}

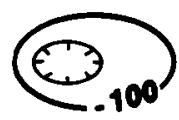

Magnetic contours-Contour interval, 10 gammas; hachures indicate depression; $\mathbf{H}$, area of magnetic high and value in gammas; $\mathrm{L}$, area of magnetic low and value in gammas

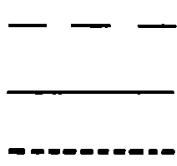

Flight path of airborne survey

Contact

Normal fault, concealed-D, downthrown side; $U$, upthrown side

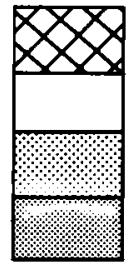

Area of identified iron resources

Quaternary and Tertiary basin deposits

Mesozoic and Paleozoic sedimentary rocks

Archean metamorphic rocks

marble. Blebs or pods less than several inches long are also found scattered throughout Type III marble, but are not found in any significant concentration except in the talcose layers described below.

Talcose pods or layers concordant with foliation of Type III marble contain most of the talc found in the wilderness study area. More than 50 percent, and perhaps as much as $\mathbf{7 0}$ percent, of all of the talc seen is in these layers. Eight of these layers were found and all have several features in common. With the exception of one occurrence (locality 2T, pl. 1, described below) they are traceable for no more than $6 \mathrm{ft}$ along strike, typically pinching out at both ends. Thickness ranges from 1 to 25 in., and estimated talc content ranges from 5 to 90 percent. Most of these layers contain calcite and less abundant dolomite. A large pod of talcose marble is exposed in the cliffs on the south side of the ridge in the SW $1 / 4 \mathrm{SE}^{1 / 4} \mathrm{SW} 1 / 4$ sec. 8 , T. 6 S., R. 5 W. (pl. 1). This pod is 13 by 13 by $6 \mathrm{ft}$ and is estimated to contain 5 to 10 percent talc in dolomitic marble.

At locality 1T (pl. 1) abundant pieces of talc 2 to $8 \mathrm{in}$. long indicate a concentration of talc in the marble of a prospect pit. Within a distance of several tens of feet to the south, many small talc pods (less than 4 in. long) occur within an exposure of Type III marble. A conformable layer (about $3 \mathrm{ft}$ thick) consisting of a mixture of talc, chlorite, and quartz is exposed approximately $6 \mathrm{ft}$ along strike to the northwest from the prospect. This layer is covered at the southeast end and pinches out at the northwest end. Talc float is abundant for several tens of feet on the slopes to the northwest. A rock consisting of a mixture of chalcedony, dolomite, and talc, some with the texture of weathered bone, also was found in float approximately $150 \mathrm{ft}$ northwest of the concentration of talc. On the basis of the abundance of talc float in this area, it is possible that there are abundant talc pods or layers within the dolomitic marble.

At locality $2 \mathrm{~T}$ (pl. 1) a poorly exposed conformable talcose layer occurs; it is $6 \mathrm{ft}$ thick, extends for about $75 \mathrm{ft}$ along strike, and is in Type III marble. Barren marble of Type III is exposed to the northeast and soil covers the layer to the northwest. Talc was not found in the Type III marble exposed either above or below the talcbearing layer. On the basis of loose blocks of talc, this $6 \times 75 \mathrm{ft}$ area either is a single body of talc or, more likely, an area in which the dolomitic marble has been largely replaced by talc.

Resource potential.-The mineral resource potential for talc in the various parts of the wilderness study area ranges from low to high. High potential with level $\mathrm{C}$ certainty is applied to three areas: (1) surrounding Ruby Peak (part of sec. 16, T. 6 S., R. 5 W.), (2) west of Ruby Peak (SE $1 / 4 N^{N} 1 / 4$ sec. 17 , T. 6 S., R. 5 W.), and (3) a small area in the $S 1 / 2$ of sec. $8, T$. 6 S., R. 5 W. Because of sparse vegetation in the three areas, they could be searched effectively for talc. On the basis of the aforementioned comparison to the Greenhorn Range, an area with similar bedrock, the concentration of talc occurrences in the three areas of the wilderness study area must be considered anomalous. A higher level of certainty would require additional data. The remainder of the large area underlain by marble in the vicinity of Ruby Peak is rated to have moderate resource potential with a level $C$ certainty. The area is underlain by marble, in part dolomitic, and scattered occurrences of talc are in the float. Bedrock is generally well exposed over much of this area.

The two isolated areas underlain by marble in the $\mathrm{NE}^{1 / 4}$ sec. 7 and NW1/4 sec. $8, T$. 6 S., R. $5 \mathrm{~W}$. are rated to have moderate resource potential for talc, with level B certainty; they are poorly exposed. The ridge underlain by marble at the western boundary of the wilderness study area, in SW1/4 sec. 12, T. $6 \mathrm{~S}$., R. $6 \mathrm{~W}$., is rated to have moderate potential with level $\mathrm{C}$ certainty. The marble is well exposed and, although talc float was not found within the wilderness study area, a small amount of talc float was found along this same layer 250 m west of the wilderness study area. Marble is exposed at the southeastern corner of the wildemess study area in the SE $1 / 4$ sec. 23 and SW $1 / 4$ sec. $24, T$. 6 S., R. 5 W. (pl. 1). Exposures of bed rock in this area are good. Because the area is underlain by marble, some of which is dolomitic, it is considered to have moderate talc potential; the level of certainty is judged to be $C$. The remainder of the area of outcropping metamorphic rocks in the wilderness study area is considered to have a low talc resource potential because of a lack of Archean marble.

The resource potential assigned to the individual areas of the exposed metamorphic rocks is based on geologic parameters that are useful only for rocks at or 
near the surface. Neither these parameters, nor geochemical and geophysical parameters, were considered useful to assess the likelihood of the occurrence of concealed talc resources. Hence, the favorability and certainty ratings apply only to those metamorphic rocks at or near the surface; the mineral resource potential for talc at depth in these areas may be lower or higher than those determined for exposed metamorphic rocks.

The mineral resource potential for talc in metamorphic rocks concealed beneath Mesozoic and Paleozoic strata is unknown, and the certainty is rated A: available information is not adequate for determination of the level of mineral resource potential. The existence and extent of marble beneath the cover of Mesozoic and Paleozoic strata are unknown, and the geologic parameters used to determine the mineral resource potential for talc are not useful in areas that are covered.

A mining company was negotiating in 1984 for mineral leases on private land near the wilderness study area and has staked claims on talc discoveries in parts of sections $19,20,29$, and 30, T. 6 S., R. 5 W., and sections 11 and 12, T. $6 \mathrm{~S} .$, R. $6 \mathrm{~W}$. (pl. 1) just to the south of the wilderness study area (Howard Harlan, Cyprus Industrial Minerals Company, written commun., October 5, 1984).

\section{Other Mineral Resources}

No phosphate deposits are known to occur in the wilderness study area. The Permian Phosphoria Formation, the sedimentary host rock for phosphate in southwestern Montana, has been eroded from the area. A possibility exists that the Ruby Range could be underlain by a thrust fault, and a remote possibility exists that Phosphoria strata may occur beneath such a thrust fault. The mineral resource potential for phosphate in the study area is rated as low, with a certainty level of $\mathrm{C}$.

Gold occurs in Archean rocks in nearby mountain ranges but no deposits are known in Archean rocks of the wilderness study area. No measurable amount of gold was found in the Archean rocks analyzed. One stream concentrate sample (9S, table 3 ) yielded a very low gold value; the sample is from the general area of a prospect (loc. 10P, pl. 1) in sheared, hydrothermally altered Archean rocks. No measurable concentration of silver was found in the rocks of this general area. The mineral resource potential for gold and silver in Archean metamorphic rocks is rated as low, with a certainty level of $\mathrm{C}$ : available information gives a good indication of the level of mineral resource potential.

Gold, silver, and base metals (copper, lead, and zinc) occur in ranges to the east, north, and northwest of the wilderness study area, and apparently are related to Laramide-age granitic intrusive rocks. No such intrusive rocks are exposed within or near the study area and no indications of concealed granitic intrusives were found during field studies or detected by geophysical studies. The mineral resource potential for gold, silver, and base metals associated with intrusive rocks is rated as low, with a certainty level of $\mathrm{C}$ : available information gives a good indication of the level of mineral resource potential.

\section{Energy Resources}

The mineral resource potential for uranium in the wilderness study area was evaluated by the U.S. Department of Energy during the National Uranium Resource Evaluation (NURE) program. The area was not classified as favorable for uranium deposits (Wodzicki and Krason, 1981). As part of this program, Broxton (1979) reported no anomalous concentrations of uranium in stream-water or stream-sediment samples taken from the wilderness study area and the immediately adjacent land. The potential for uranium resources is rated as low, with a certainty level of $\mathrm{C}$.

The oil and gas potential on Federal Wilderness Lands in Montana was evaluated by Perry and others (1983). To facilitate the evaluation, they subdivided the lands into geologically related appraisal areas. The appraisal area within which the wilderness study area lies was assigned a low potential for oil and gas resources (Perry and others, 1983, p. G15). They noted that the appraisal area contains a broad distribution of Archean metamorphic rocks and Tertiary volcanic rocks at the surface, and lacks known source beds for hydrocarbons. Recent studies of the structural development of the foreland of southwestern Montana indicate that some areas of Archean metamorphic basement rocks have been displaced by thrust faults. Recognition of these thrust faults leads to a possibility that the wilderness study area could be underlain by a thrust fault, and if so, potentially hydrocarbon-bearing sedimentary strata may exist beneath such a thrust. Seismic data or drilling is needed to determine if this possibility is real. The low potential of the wilderness study area is assigned a certainty level of $B$.

No geothermal resources are known to exist within or immediately adjacent to the wilderness study area.

\section{REFERENCES CITED}

Bayley, R. W., and James, H. L., 1973, Precambrian ironformations of the United States: Economic Geology, v. 68, p. 934-959.

Berg, R. B., 1979, Talc and chlorite deposits in Montana: Montana Bureau of Mines and Geology Memoir 45, 66 p.

1987, Potential for talc deposits within the BLM Wilderness Study Area of the northern part of the Ruby Range, Madison County, Montana: U.S. Geological Survey OpenFile Report 87-001. 
1987, Potential for talc deposits within the BLM Wilderness Study Area of the northern part of the Ruby Mountains, Madison County, Montana: U.S. Geological Survey OpenFile Report 87-001.

Broxton, D. E., 1979, Uranium hydrogeochemical and stream sediment reconnaissance of the Dillon NTMS quadrangle, Montana/Idaho, including concentrations of forty-three additional elements: U.S. Department of Energy Open File Report GJBX-38, 228 p. (Los Alamos Scientific Laboratory Report LA-7347-MS).

Burfiend, W. J., 1967, A gravity investigation of the Tobacco Root Mountains, Jefferson Basin, Boulder batholith, and areas of southwestern Montana: Bloomington, Indiana University, Ph. D. dissertation, $90 \mathrm{p}$.

Cordell, L. E., Keller, G. R., and Hildenbrand, T. G., 1982, Bouguer gravity map of the Rio Grande Rift: U.S. Geological Survey Geophysical Investigations Map GP-949, scale $1: 1,000,000$.

Garihan, J. M., 1973, Origin and controlling factors of the talc deposits of steatite grade in the central Ruby Range, southwestem Montana: Geological Society of America, Northeastern Section Meeting, Abstracts with Programs, v. 5, no. 2, p. 164.

Giletti, B. J., 1966, Isotopic ages from southwestem Montana: Journal of Geophysical Research, v. 71, p. 4029-4036.

Godson, R. H., and Webring, M. W., 1982, CONTOUR: A modification of G.I. Evenden's general purpose contouring program: U.S. Geological Survey Open-File Report 82-797, $32 \mathrm{p}$.

Goudarzi, G. H., 1984, Guide to preparation of mineral survey reports on public lands: U.S. Geological Survey Open-File Report 84-787, 30 p.

Grimes, D. J., and Marranzino, A. P., 1968, Direct-current arc and alternating-current spark emission spectrographic field methods for the semiquantitative analysis of geologic materials: U.S. Geological Survey Circular 591, 6 p.

Hammer, Sigmund, 1939, Terrain corrections for gravimeter stations: Geophysics, v. 4, p. 184-194.

Hassemer, J. H., and Kaufmann, H. E., 1986, Principal facts for the gravity stations in the Dillon $1^{\circ} \times 2^{\circ}$ quadrangle, Montana and Idaho: National Technical Information Service PB86-197407/AS, 6 p.

James, H. L., 1981, Bedded Precambrian iron deposits of the Tobacco Root Mountains, southwestern Montana: U.S. Geological Survey Professional Paper 1187, 16 p.

James, H. L, and Hedge, C. E., 1980, Age of the basement rocks of southwest Montana: Geological Society of America Bulletin, v. 91, p. 11-15.

James, H. L., and Wier, K. L., 1972, Geologic map of the Kelly iron deposit, Sec. 25., T. 6 S., R. 5 W., Madison County, Montana: U.S. Geological Survey Miscellaneous Field Studies Map MF-349, scale 1:800.

Karasevich, L. P., 1980, Structure of the pre-Beltian metamorphic rocks of the northern Ruby Range, southwestern Montana: Pennsylvania State University, MS thesis, 172 p.

1981, Geologic map of the northern Ruby Range, Madison County, Montana: Montana Bureau of Mines and Geology Geologic Map 25, scale 1:24,000.
Karasevich, L. P., Garihan, J. M., Dahl, P. S., and Okuma, A. F., 1981, Summary of Precambrian metamorphic and structural history, Ruby Range, southwest Montana: Montana Geological Society Field Conference and Symposium Guidebook to Southwest Montana, p. 225-237.

Kaufmann, H. E., and Hanna, W. F., 1982, Slides showing preliminary mosaic aeromagnetic and complete Bouguer gravity anomaly maps of the Dillon $1^{\circ} \times 2^{\circ}$ quadrangle, Montana and Idaho: U.S. Geological Survey Open-File Report 82-604, $235 \mathrm{~mm}$ slides, 6 pages text.

Kaufmann, H. E., Sorenson, S. B., and O’Neill, K. J., 1983, Principal facts and complete Bouguer gravity anomaly map for the Dillon $1^{\circ} \times 2^{\circ}$ quadrangle, Montana and Idaho: U.S. Geological Survey Open-File Report 83-51, 75 p.

Perry, W. J., Jr., Rice, D. D., and Maughan, E. K., 1983, Petroleum potential of wilderness lands in Montana: U.S. Geological Survey Circular 902-G, 23 p.

Petkewich, R. W., 1972, Tertiary geology and paleontology of the Beaverhead east area, southwestern Montana: Missoula, University of Montana, Ph.D. dissertation, 343 p.

Plouff, Donald, 1977, Preliminary documentation for a FORTRAN program to compute gravity terrain corrections based on topography digitized on a geographic grid: U.S. Geological Survey Open-File Report 77-535, 45 p.

Schmauch, S. W., 1985, Mineral resources of the Ruby Mountains Study Area Madison County, Montana: U.S. Bureau of Mines Open File Report 63-85, 10 p.

Schmidt, C. J., and Garihan, J. M., 1983, Laramide tectonic development of the Rocky Mountain foreland of southwestern Montana, in Lowell, J. D., and Gries, Robbie, eds., Rocky Mountain Foreland Basins and Uplifts: Denver, Rocky Mountain Association of Geologists, p. 271-294.

Thompson, C. E., Nakagawa, H. M., and Van Sickle, G. H., 1968, Rapid analysis for gold in geologic materials, in Geological Survey Research: U.S. Geological Survey Professional Paper 600-B, p. B130-B132.

Tysdal, R. G., 1970, Geology of the north end of the Ruby Range, southwestem Montana: U.S. Geological Survey Open-File Report 1436, 187 p.

1976a, Geologic map of the northern part of the Ruby Range, Montana: U.S. Geological Survey Miscellaneous Investigations Map I-951, scale 1:24,000.

1976b, Paleozoic and Mesozoic stratigraphy of the northern part of the Ruby Range, southwestern Montana: U.S. Geological Survey Bulletin 1405-1, 26 p.

1981, Foreland deformation in the northern part of the Ruby Range of southwestern Montana: Montana Geological Society Field Conference and Symposium Guidebook to Southwest Montana, p. 215-224.

U.S. Bureau of Mines and U.S. Geological Survey, 1980, Principles of a resource/reserve classification: U.S. Geological Survey Circular 831,5 p.

U.S. Geological Survey, 1975, Aeromagnetic map of southwestem Montana and east-central Idaho: U.S. Geological Survey Open-File Report 75-655, scale 1:250,000. 
Viets, J. G., Clark, J. R., and Campbell, W. L., 1984, A rapid, partial leach and organic separation for the sensitive determination of $\mathrm{Ag}, \mathrm{Bi}, \mathrm{Cd}, \mathrm{Co}, \mathrm{Mo}, \mathrm{Pb}, \mathrm{Sb}$, and $\mathrm{Zn}$ in surface geologic materials by flame atomic absorption: Journal of Geochemical Exploration, v. 20, p. 355-366.

Webring, M. W., 1981, MINC: A gridded program based on minimum curvature: U.S. Geological Survey Open-File Report 81-1224, $12 \mathrm{p}$.
Wodzicki, Antoni, and Krason, Jan, 1981, National uranium resource evaluation, Dillon quadrangle, Montana and Idaho: U.S. Department of Energy Open-File Report (GJQ$007(81), 81 \mathrm{p}$.

Woollard, G. P., 1979, The new gravity system-changes in international gravity base values and anomaly values: Journal of Geophysical Research, v. 44, p. 1352-1366. 
APPENDIX 


\title{
DEFINITION OF LEVELS OF MINERAL RESOURCE POTENTIAL AND CERTAINTY OF ASSESSMENT
}

\author{
Definitions of Mineral Resource Potential
}

LOW mineral resource potential is assigned to areas where geologic, geochemical, and geophysical characteristics define a geologic environment in which the existence of resources is unlikely. This broad category embraces areas with dispersed but insignificantly mineralized rock as well as areas with few or no indications of having been mineralized.

MODERATE mineral resource potential is assigned to areas where geologic, geochemical, and geophysical characteristics indicate a geologic environment favorable for resource occurrence, where interpretations of data indicate a reasonable likelihood of resource accumulation, and (or) where an application of mineral-deposit models indicates favorable ground for the specified type(s) of deposits.

HIGH mineral resource potential is assigned to areas where geologic, geochemical, and geophysical characteristics indicate a geologic environment favorable for resource occurrence, where interpretations of data indicate a high degree of likelihood for resource accumulation, where data support mineral-deposit models indicating presence of resources, and where evidence indicates that mineral concentration has taken place. Assignment of high resource potential to an area requires some positive knowledge that mineral-forming processes have been active in at least part of the area.

UNKNOWN mineral resource potential is assigned to areas where information is inadequate to assign low; moderate, or high levels of resource potential.

NO mineral resource potential is a category reserved for a specific type of resource in a well-defined area.

\section{Levels of Certainty}

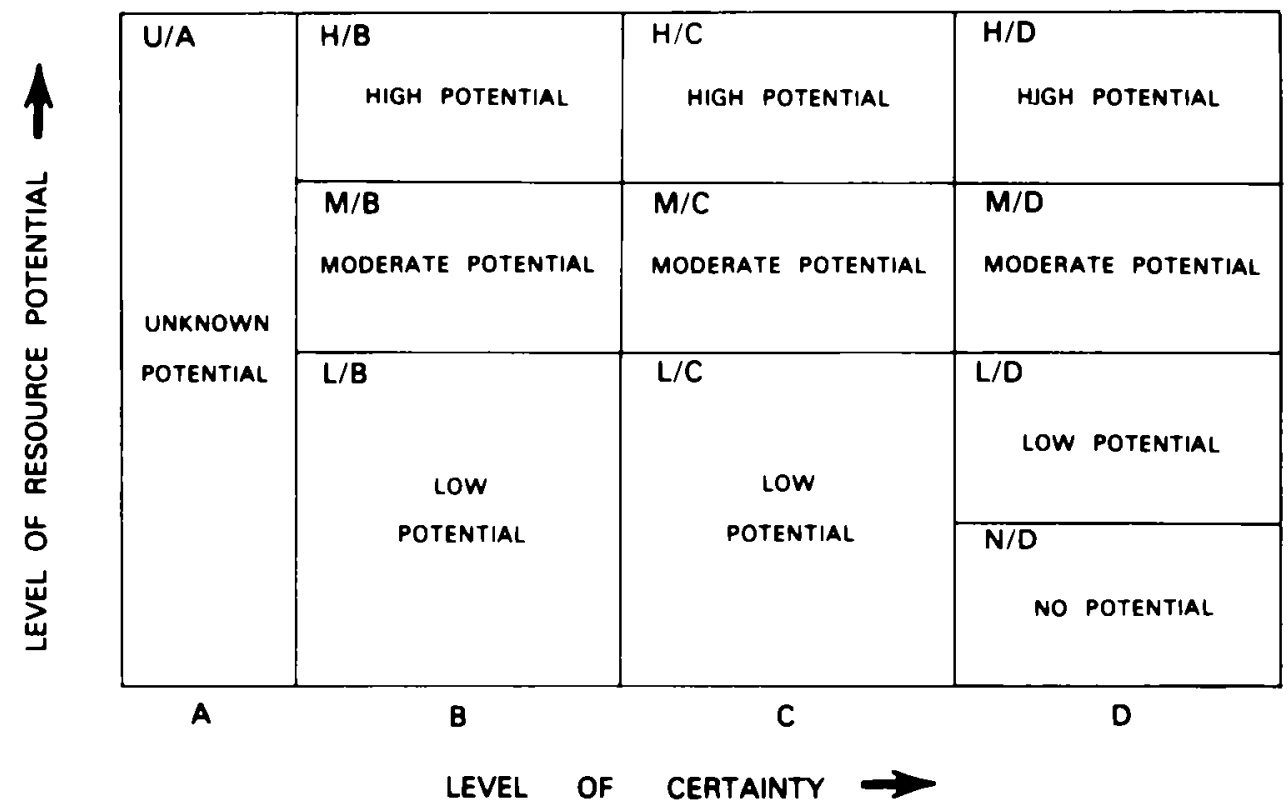

A. Available information is not adequate for determination of the level of mineral resource potential.

B. Available information suggests the level of mineral resource potential.

C. Available information gives a good indication of the level of mineral resource potential.

D. Available information clearly defines the level of mineral resource potential.

\section{Abstracted with minor modifications from:}

Taylor, R. B., and Steven, T. A., 1983, Definition of mineral resource potential: Economic Geology, v. 78, no. 6, p. $1268-1270$.

Taylor. R. B.. Stoneman, R. J., and Marsh, S. P., 1984. An assessment of the mineral resource potential of the San Isabel National Forest, south-central Colorado: U.S. Geological Survey Bulletin 1638, p. $40-42$.

Goudarzi, G. H., compiler, 1984, Guide to preparation of mineral survey reports on public lands: U.S. Geological Survey Open-File Report 84-0787, p. 7, 8. 


\begin{tabular}{|c|c|c|c|c|c|}
\hline & \multicolumn{5}{|c|}{ RESOURCE / RESERVE CLASSIFICATION } \\
\hline & \multicolumn{3}{|c|}{ IDENTIFIED RESOURCES } & \multicolumn{2}{|c|}{ UNDISCOVERED RESOURCES } \\
\hline & \multicolumn{2}{|c|}{ Demonstrated } & \multirow{2}{*}{ Inferred } & \multicolumn{2}{|c|}{ Probability Range } \\
\hline & Measured & Indicated & & Hypothetical & Speculative \\
\hline ECONOMIC & & & Inferred Reserves & & \\
\hline $\begin{array}{l}\text { MARGINALLY } \\
\text { ECONOMIC }\end{array}$ & Margin & eserves & $\begin{array}{c}\text { Inferred } \\
\text { Marginal Reserves }\end{array}$ & & \\
\hline $\begin{array}{c}\text { SUB- } \\
\text { ECONOMIC }\end{array}$ & $\begin{array}{r}\text { Dem } \\
\text { Subeconor }\end{array}$ & $\begin{array}{l}\text { strated } \\
\text { Resources }\end{array}$ & $\begin{array}{c}\text { Inferred } \\
\text { Subeconomic } \\
\text { Resources }\end{array}$ & & \\
\hline
\end{tabular}

Major elements of mineral resource classification, excluding reserve base and inferred reserve base. Modified from U. S. Bureau of Mines and U. S. Geological Survey, 1980, Pririciples of a resource/reserve classification for minerals: U. S. Geological Survey Circular 831, p. 5. 
GEOLOGIC TIME CHART

Terms and boundary ages used by the U.S. Geological Survey, 1986

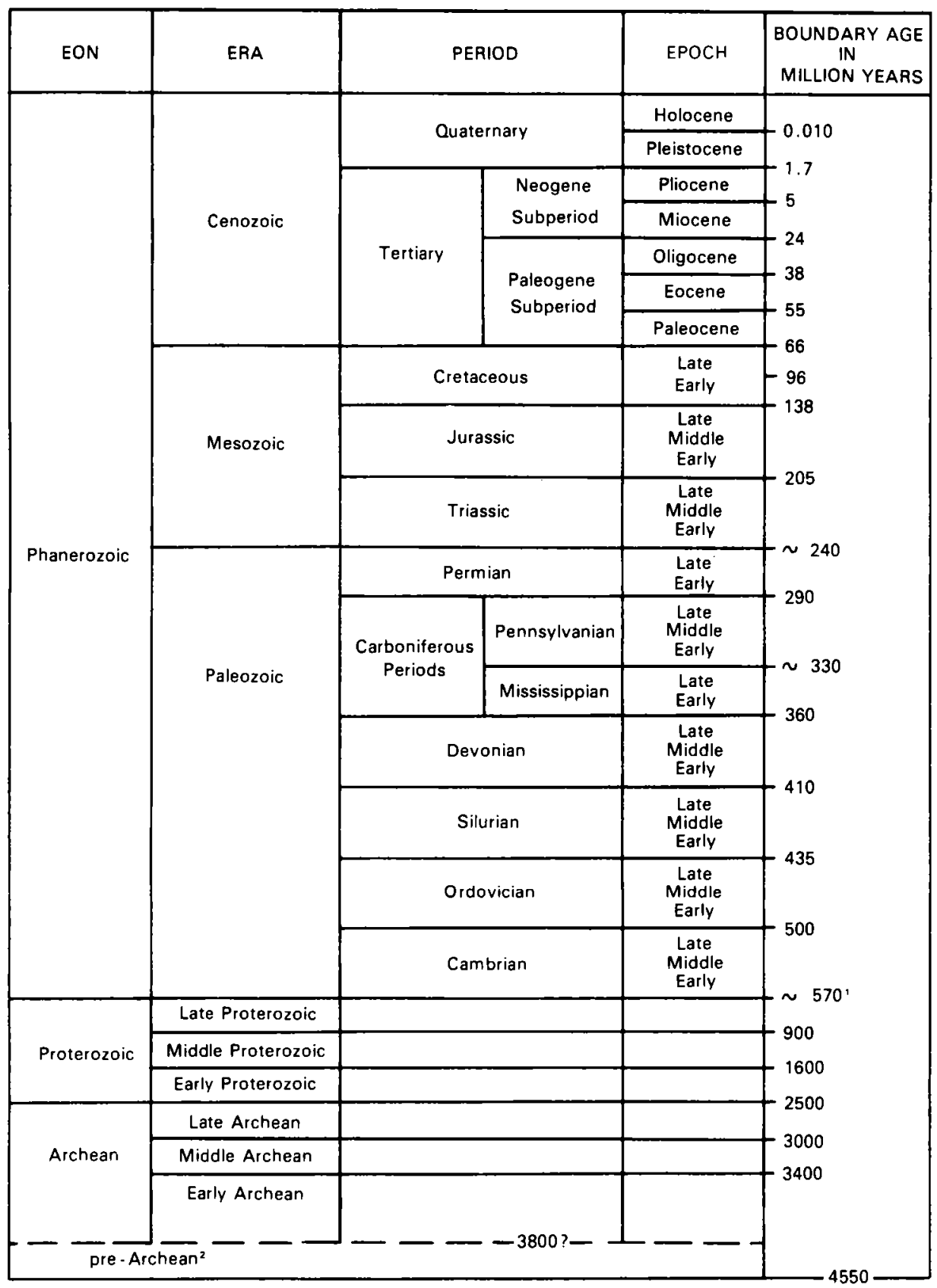

'Rocks older than 570 m.y. also called Precambrian, a time term without specific rank

${ }^{2}$ Informal time term without specific rank. 


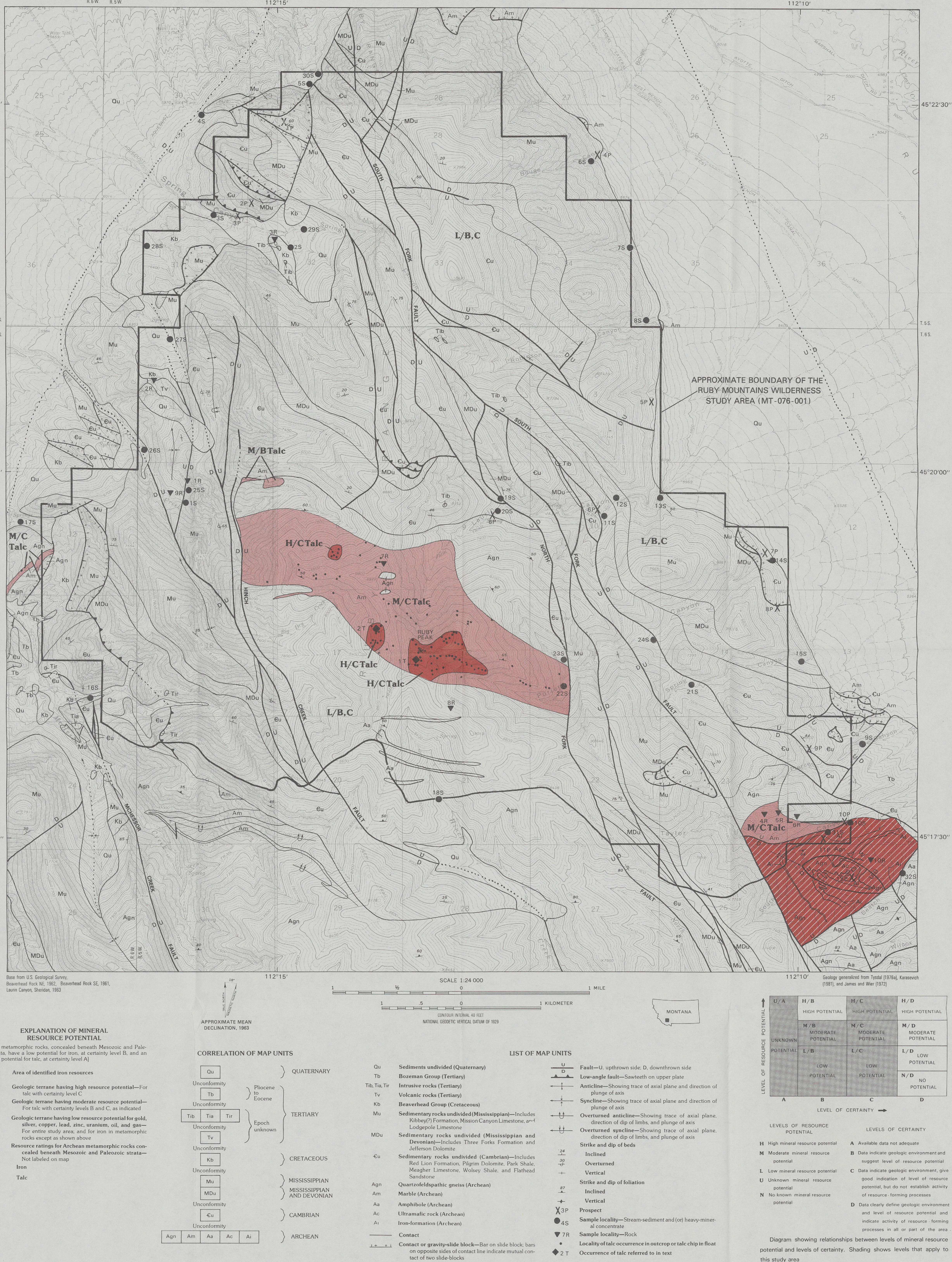


